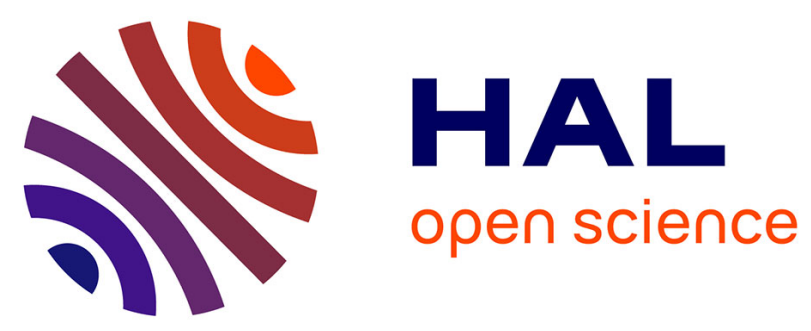

\title{
Cation Migration and Structural Deformations upon Dehydration of Nickel-Exchanged NaY Zeolite: A Combined Neutron Diffraction and Monte Carlo Study
}

Wilfried Louisfrema, Jean-Louis Paillaud, Florence Porcher, Elsa Perrin, Thomas Onfroy, Pascale Massiani, Anne Boutin, Benjamin Rotenberg

\section{To cite this version:}

Wilfried Louisfrema, Jean-Louis Paillaud, Florence Porcher, Elsa Perrin, Thomas Onfroy, et al.. Cation Migration and Structural Deformations upon Dehydration of Nickel-Exchanged NaY Zeolite: A Combined Neutron Diffraction and Monte Carlo Study. Journal of Physical Chemistry C, 2016, 120 (32), pp.18115-18125. 10.1021/acs.jpcc.6b05657 . hal-01485629

\section{HAL Id: hal-01485629 \\ https://hal.sorbonne-universite.fr/hal-01485629}

Submitted on 13 Nov 2018

HAL is a multi-disciplinary open access archive for the deposit and dissemination of scientific research documents, whether they are published or not. The documents may come from teaching and research institutions in France or abroad, or from public or private research centers.
L'archive ouverte pluridisciplinaire HAL, est destinée au dépôt et à la diffusion de documents scientifiques de niveau recherche, publiés ou non, émanant des établissements d'enseignement et de recherche français ou étrangers, des laboratoires publics ou privés. 


\section{Page 1 of 35}

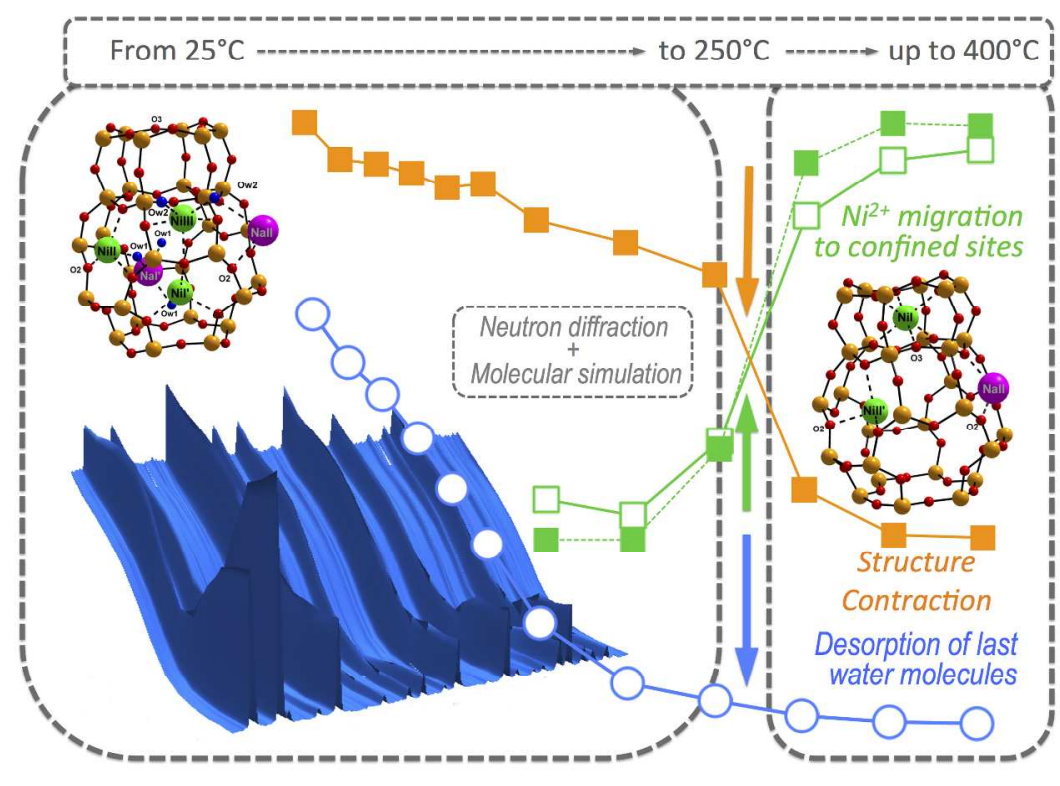

Graphical Abstract

$519 \times 344 \mathrm{~mm}(150 \times 150 \mathrm{DPI})$ 


\title{
Cation Migration and Structural Deformations upon Dehydration of Nickel-Exchanged NaY Zeolite: A Combined Neutron Diffraction and Monte Carlo Study
}

\author{
Wilfried Louisfrema, ${ }^{a, b, c}$ Jean-Louis Paillaud, ${ }^{d}$ Florence Porcher, ${ }^{e, f}$ Elsa Perrin, ${ }^{b, c}$ Thomas \\ Onfroy, ${ }^{g, h}$ Pascale Massiani, ${ }^{g, h, *}$ Anne Boutin, ${ }^{b, c}$ Benjamin Rotenberg ${ }^{a}$
}

a Sorbonne Universités, UPMC Univ Paris 06, CNRS, UMR 8234 PHENIX, Case courrier 51, 4 place Jussieu, 75252 Paris Cedex 5, France

b Ecole Normale Supérieure, PSL Research University, UPMC Univ Paris 06, CNRS, Département de Chimie, PASTEUR, 24, rue Lhomond, 75005 Paris, France

c Sorbonne Universités, UPMC Univ Paris 06, ENS, CNRS, PASTEUR, 75005 Paris, France

d Equipe Matériaux à Porosité Contrôlée (MPC), Institut de Science des Matériaux de Mulhouse (IS2M), Université de Haute-Alsace (UHA), CNRS, UMR 7361, 3bis rue Alfred Werner, 68093 Mulhouse Cedex, France

e Laboratoire Léon Brillouin (LBB), CEA, CNRS UMR 12, Bât. 563 CEA Saclay, 91191 Gif sur Yvette Cedex, France

f Laboratoire de Cristallographie, Résonance Magnétique et Modélisations $\left(\mathrm{CRM}^{2}\right)$, Université de Lorraine, Faculté des Sciences et Technologies, CNRS, UMR 7036, Boulevard des Aiguillettes, BP 70239, 54506 Vandoeuvre-lès-Nancy, France.

g Sorbonne Universités, UPMC Univ Paris 06, Laboratoire de Réactivité de Surface (LRS), 4 place Jussieu, 75005 Paris, France

h CNRS UMR 7197, Laboratoire de Réactivité de Surface (LRS), Case courrier 178, 4 place Jussieu, 75252 Paris Cedex 05, France

\section{Corresponding author:}

Pascale Massiani, Laboratoire de Réactivité de Surface (LRS), CNRS UMR 7197, UPMC, 4 place Jussieu, F-75005 Paris, France, E-mail: pascale.massiani@upmc.fr 


\begin{abstract}
Combining neutron diffraction and classical molecular simulations, we describe the cations migration and associated structural changes taking place in a Ni-exchanged NaY faujasite zeolite upon stepwise dehydration from room temperature up to $400^{\circ} \mathrm{C}$. The cation redistribution between sites and the associated framework deformations taking place upon water removal are identified and quantified. Neutron diffraction allows monitoring the zeolite structure, the average cation location and the water content, while molecular modeling provides insights into the correlations between the positions of cations and water molecules. Importantly, we demonstrate that the migration of $\mathrm{Ni}^{2+}$ toward highly confined sites upon dehydration is the driving force behind deformation of the hexagonal prisms. The present work illustrates the relevance of combining these two experimental and theoretical approaches to clarify the complex interplay between cation hydration, cation location and framework deformation. It also underlines the importance to capture the flexibility of the framework in molecular simulation of hydrated zeolite in particular when multivalent ions are involved.
\end{abstract}

Keywords: Faujasite zeolite, Nickel, Cation migration, Dehydration, Monte Carlo simulations, Neutron diffraction, Neutron scattering, Rietveld refinement 


\section{1) INTRODUCTION}

Zeolites are crystalline aluminosilicates well known for their unique organized networks of nanopores and their adsorption and cation exchange properties. Their three-dimensional frameworks (231 known topologies ${ }^{1}$ ) consist of ordered assemblies of building units made of tetrahedral $\mathrm{T}$ atoms (commonly $\mathrm{Si}$ and $\mathrm{Al}$ ) bridged by oxygen ones. Each type of $\mathrm{TO}_{2}$ zeolite framework defines specific cages and channels (void volume) whose organization (regular) and sizes (4-20 $\AA$, similar to those of many molecules) are at the origin of the wide use of zeolites in domains such as adsorption, separation or shape-selective catalysis. Besides porosity, an important feature of zeolites lies in the tetrahedral aluminum atoms present as $\mathrm{Al}^{3+}$ in their $\mathrm{TO}_{2}$ lattice, which generates framework negative charges (one per framework $\mathrm{Al}$ atom) that are neutralized by charge compensating cations (alkali, protons, transition metal ions...) located in their proximity, in the pores. These cations are easily exchangeable, especially in aqueous solution, a property widely used in processes where removal of undesired ions is needed (additives in laundry detergents, water softener, purification of metal polluted soils or of effluents). The exchange capacity of zeolites also allows the easy tuning of their cationic composition, which is at the basis of their extensive applications as metals supports in heterogeneous catalysis, ${ }^{2}$ as selective gas adsorbents or separators ${ }^{3}$ or as tunable materials in the photovoltaic, medicine or sensors fields. ${ }^{4}$

To achieve proper control of the zeolite performances, many parameters must be understood, including structural, morphological and chemical properties. Amongst them, not only (i) the nature of the exchanged cations and their content in the solid but also (ii) their location and distribution amongst the cationic sites as well as (iii) their interaction with the surrounding framework and molecules adsorbed in the pores are important. Hence, many studies have been dedicated to the understanding of alkali cation features in these solids, from the pioneering works of Barrer ${ }^{5}$ and Breck and Flanigen ${ }^{6}$ on synthetic zeolites, to the numerous subsequent works as reviewed in the late $90 \mathrm{~s}^{7}$ Similarly, the identification of the location and environment of metal cations, including transition ones, in partially exchanged metal zeolites used as catalysts ${ }^{8}$ in DeNOx, ${ }^{9-12}$ methanol conversion ${ }^{13}$ or methane activation ${ }^{14}$ has prompted a tremendous number of works. For these reactions that take place in the gas phase, combined experimental (often spectroscopic) and theoretical (Density Functional Theory, DFT) studies are frequently performed to provide a proper description, at a local scale, of the metal site configuration and of its environment. ${ }^{15-17}$ From these works, it is now well established that many parameters such as the structure type, the framework composition or the nature of the 
co-cations (ensuring solid neutrality) strongly influence the transition metal cation configuration. ${ }^{18-23}$ In addition, the propensity of cations to move from one particular site to another (possibly in a distinct cage) upon addition of molecules, for instance adsorbed water or a reactant, has been largely demonstrated. ${ }^{24-26}$

Nevertheless, due to the entailed computational cost of DFT, accurate theoretical descriptions are currently limited to clusters containing only up to a few 10-100 atoms. For zeolites, in which unit cells usually contain more than $100 \mathrm{TO}_{2}$ tetrahedra (i.e. more than 300 framework atoms), this means that only small portions of the overall lattice can be considered. Therefore, DFT alone is not sufficient to describe larger systems such as those involving the migration of a cation from one cage to another, or the adsorption of many molecules, as occurs in cation exchange in aqueous solution. A way to overcome such limitation consists in performing classical molecular simulation (molecular dynamics or Monte Carlo methods), which allows taking into account a much larger (compared to DFT) part of the framework, at the price of using simpler models of interactions between atoms. ${ }^{27}$ Such force fields are now quite well established for porous aluminosilicates containing light exchangeable cations (e.g. in zeolites $^{28-29}$ and in clays ${ }^{30-33}$ ), but not yet in presence of heavy ones as the noble or transition metals involved in catalysts or the heavy elements trapped in adsorbents after nuclear effluents purification. Despite a few recent successes of molecular simulation (e.g. water adsorption in partially exchanged Co-NaX faujasite ${ }^{34}$ ), the question of adsorption-induced redistribution of multivalent cations amongst the possible sites and its coupling to the framework deformations remains largely open. A reason for that is the challenge posed by the simultaneous experimental determination of the framework structure and of the cations and water molecules locations.

In the context of understanding the migration of multivalent cations upon water adsorption (or desorption), we recently demonstrated the power of neutron diffraction. Compared to X-ray absorption spectroscopy (XAS) that gives an average picture of the $\mathrm{Ni}^{2+}$ ions environment (coordination, nature, number and distances of neighbouring atoms), ${ }^{25,35}$ neutron diffraction can provide simultaneously (i) structural information (precise identification of framework sites and of average cationic sites occupancies) and (ii) quantitative measurement of the residual water content (thanks to the incoherent signal resulting from neutron scattering by the ${ }^{1} \mathrm{H}$ hydrogen atoms of water molecules). ${ }^{36}$ However, the localization of water still remains difficult, especially when different locations and therefore different environments coexist. 
In the present work, we combine this neutron scattering approach to classical molecular simulations in order to analyze in detail the redistribution of cations in Ni-exchanged $\mathrm{NaY}$ faujasite $(7 \%$ wt $\mathrm{Ni})$ upon dehydration and its coupling to the deformation of the zeolite framework. Thus, we apply neutron diffraction to monitor both in real time and quantitatively the simultaneous water removal and structural changes upon stepwise heating from 25 to $400^{\circ} \mathrm{C}$. Then, we perform Monte Carlo simulations of the same system, using the experimental structure and water content identified at each temperature, following our recently introduced method allowing to localize cations from their local environment instead of the crystallographic coordinates of the sites. ${ }^{37} \mathrm{We}$ validate the simulation results by comparing the experimental and calculated $\mathrm{Na}^{+}$and $\mathrm{Ni}^{2+}$ distributions among cationic sites (and their evolution with water content). Finally, we discuss the coupling between framework deformation and water and cation locations. Materials and methods are described in Section 2, while results are presented in Section 3.

\section{2) MATERIALS AND METHODS}

\section{1) Ni-NaY faujasite}

Hydrated Ni-NaY faujasite was taken as a representative zeolite system to conduct the study for four reasons. Firstly, this new work is positioned in the continuation of our previous studies on dehydrated $\mathrm{Ni}^{2+}$-exchanged $\mathrm{NaX}$ faujasite ${ }^{35,38}$ in which we discussed the effect of framework basicity ${ }^{39-40}$ on $\mathrm{Ni}^{2+}$ configuration. Secondly, faujasite is commonly obtained in the form of octahedral crystal habits of few microns in size, having high crystallinity and few structural defects, being therefore one of the best zeolite candidate to obtain "artifact free" experimental data that can be compared to modeling ones. Thirdly, the faujasite structure (FAU type $)^{1}$ has been the most widely studied amongst zeolites and distinction between its several crystallographic cationic sites is now well established (especially for $\mathrm{Na}^{+}$-exchanged faujasite) ${ }^{7}$ this should facilitate sites identification even if their exact position and occupancy can vary depending on the cations nature and content, as it has been recently demonstrated for K-FAU, ${ }^{41}$ amongst other examples. Fourthly, the FAU structure contains three distinct types of cages (known as supercages, sodalites and hexagonal prisms) between which transition metal ions tend to migrate depending on the hydration state, ${ }^{42}$ which is well suited for a study of cations rearrangement. For nickel, it is currently assumed that its location in hydrated samples is in supercages that are big enough (pore diameters of the order of $13 \AA)^{1}$ to accommodate the hexahydrate $\mathrm{Ni}^{2+}$ cluster, whereas after dehydration $\mathrm{Ni}^{2+}$ is preferentially 
found in more confined environments (inside the double 6-membered-rings) where it can optimize its coordination by interacting with the framework oxygen atoms. ${ }^{43-44}$

\section{2) Sample preparation}

The parent NaY zeolite was a Linde SK-40 zeolite from Union Carbide Corporation with framework unit cell composition $\mathrm{Na}_{58} \mathrm{Al}_{58} \mathrm{Si}_{134} \mathrm{O}_{384}(\mathrm{Si} / \mathrm{Al}$ ratio $=2.3)$. Introduction of the $\mathrm{Ni}^{2+}$ cations was done by exchange in solution as follows: $1 \mathrm{~g}$ of hydrated $\mathrm{NaY}$ (approx. $0.75 \mathrm{~g}$ of dry solid) was suspended in $35 \mathrm{~mL}$ of distilled water under stirring, then the $\mathrm{pH}$ of the suspension (initially at 10.1) was adjusted to 7.5 by adding 5 drops of a $0.5 \mathrm{M} \mathrm{HNO}_{3}$ solution. Next, $16 \mathrm{~mL}$ of a $0.2 \mathrm{M} \mathrm{Ni}\left(\mathrm{NO}_{3}\right)_{2}$ solution were added drop by drop and the suspension was let under stirring at RT for $5 \mathrm{~h}$. At the end of the ion-exchange process, the $\mathrm{pH}$ was 7 , preventing protonation of the zeolite. ${ }^{45-46}$ The solid was recovered by centrifugation and the exchange procedure was repeated 3 times. After the fourth exchange, the solid was washed three times in distilled water (recovered each time by centrifugation) and dried overnight at $60^{\circ} \mathrm{C}$ in static in an oven. The green (hydrated sample) and pink (dried sample) color of the sample attested the $\mathrm{Ni}^{2+}$-exchange process. Before analyses, the sample was let to rehydrate in room atmosphere for several weeks (full ambient rehydration). Its framework unit cell composition was $\mathrm{Ni}_{18} \mathrm{Na}_{22} \mathrm{Si}_{134} \mathrm{Al}_{58} \mathrm{O}_{384}$ as determined by elemental analysis (wavelength dispersive X-ray fluorescence spectroscopy, PHILIPS MagiX apparatus), hence the sample will be hereafter named $\mathrm{Ni}_{18} \mathrm{Na}_{22} \mathrm{Y}$. An important point to notice is the number of nickel atoms per unit cell (18), close to the number of hexagonal prisms per unit cell (16). Note also that this composition corresponds to $7.7 \mathrm{wt} \%$ nickel in the dehydrated material (slightly below the nickel content in the exchange solution - $96 \mathrm{mg}$ for $1 \mathrm{~g}$ of dry zeolite - due to some nickel loss during centrifugation and washing steps).

\section{3) Thermogravimetric analyses}

The water content in the sample at the start of the neutron diffraction experiments was estimated from thermogravimetric analyses (TGA) performed under distinct evacuation conditions. In the first measurement, the hydrated sample (previously kept at room temperature and pressure) was placed in a STD Q600 thermobalance (TA Instrument) and the weight loss was measured while heating from $20^{\circ} \mathrm{C}$ up to $900^{\circ} \mathrm{C}$ in flowing air $\left(20 \mathrm{~mL} \cdot \mathrm{min}^{-1}\right.$, 1013 mbar). In the second measurement, the hydrated sample was evacuated at $20^{\circ} \mathrm{C}$ under $1.33 \times 10^{-2}$ mbar during $4 \mathrm{~h}$ to reach equilibrium, then TGA was performed up to $800{ }^{\circ} \mathrm{C}$ on a 
TG Mettler Toledo STARe apparatus in flowing air $\left(100 \mathrm{~mL} \cdot \mathrm{min}^{-1}\right)$. The third experiment was conducted in a Hiden Isochema IGA-001 gas sorption microbalance: the hydrated sample was evacuated at $4 \times 10^{-6}$ mbar at $20^{\circ} \mathrm{C}$ overnight to ensure weight stabilization, then the weight loss was measured while increasing the temperature up to $450^{\circ} \mathrm{C}$. Note that this maximum temperature was lower than above because being sufficient to ensure full dehydration under high vacuum conditions.

\section{4) Neutron Diffraction}

Neutron powder diffraction patterns were recorded on the two-axis powder diffractometer G4-1 of the LLB-Orphée facility at CEA/Saclay (France). This diffractometer is equipped with a vertically focusing 200 pyrolytic graphite monochromator (nominal wavelength of $2.4226 \AA)$ and with an 800 -cell multi-detector covering an $80^{\circ}$ range in $2 \theta\left(\Delta \theta=0.1^{\circ}\right.$ between two detectors). The sample (about $300 \mathrm{mg}$ ) was introduced in an open vanadium can and loaded in a vacuum furnace $\left(\mathrm{P} \sim 10^{-6} \mathrm{mbar}\right)$ to avoid any parasitic signal arising from the interaction of neutrons with air (notably moisture). A first diffractogram was recorded after a 2 hours pumping at room temperature. Then, vacuum was maintained and the temperature was raised stepwise up to $400^{\circ} \mathrm{C}\left(2^{\circ} \mathrm{C} \cdot \mathrm{min}^{-1}\right)$ with intermediate steps lasting at least $60 \mathrm{~min}$ at constant temperatures to ensure stable intermediate hydration states (partially hydrated sample). Series of 5 diffractograms in the $2 \theta$-range $8-88^{\circ}$ were continuously recorded (15 min exposure each), both during heating (1 diffractogram) and steady temperature steps (4 diffractograms). After the last step at $400^{\circ} \mathrm{C}$, the sample was cooled down to room temperature (still under vacuum) and a last powder pattern was collected (dehydrated sample). In order to analyse the continuous ${ }^{1} \mathrm{H}$ incoherent signal, the patterns analysed were subtracted from the sample holder signal. Rietveld refinements were performed with the GSAS package $^{47}$ on the complete pattern via the EXPGUI interface. ${ }^{48}$ Moreover, the pressure in the evacuation chamber was continuously monitored to further inform on the water removal process. Additional details on the crystal structure investigation and on Rietveld plots analyses at steady temperatures can be obtained from Fachinformationszentrum Karlsruhe, 76344 Eggenstein-Leopoldshafen, Germany (fax: +49 7247808 666; e-mail: crystaldata@fizkarlsruhe.de) under depository numbers CSD-431352 (150 $\left.{ }^{\circ} \mathrm{C}\right), \mathrm{CSD}-431353\left(200^{\circ} \mathrm{C}\right)$, CSD$431354\left(250^{\circ} \mathrm{C}\right), \mathrm{CSD}-431355\left(300^{\circ} \mathrm{C}\right), \mathrm{CSD}-431356\left(350^{\circ} \mathrm{C}\right), \mathrm{CSD}-431357\left(400^{\circ} \mathrm{C}\right)$ and CSD-431358 (dehydrated back to $20^{\circ} \mathrm{C}$ ). 


\section{5) Monte Carlo Simulations}

The Monte Carlo (MC) simulations were done following an approach detailed recently. ${ }^{37}$ They were performed using a simple force field, whereby all interactions between framework atoms, cations and water molecules are described by pairwise additive potentials of the Coulomb (electrostatic interactions) and Lennard-Jones (repulsion and dispersion) forms. The parameters were taken from Jaramillo et al. ${ }^{49}$ for the zeolite framework (in particular, Si and Al atoms are described as "T atoms" carrying identical charges), from Dang ${ }^{50}$ for $\mathrm{Na}^{+}$cations and from Jeffroy et $a l .{ }^{34}$ for $\mathrm{Ni}^{2+}$ cations, together with the TIP4P water model of water. ${ }^{51}$ This force field was successfully used in previous studies of water adsorption in $\mathrm{Y}$ and $\mathrm{X}$ zeolites. ${ }^{52}$

Periodic boundary conditions were used, electrostatic interactions were computed using Ewald summation and a cut-off equal to half the box length was used to compute LennardJones interactions. At each temperature, the simulation was carried out (i) by considering the experimental framework measured at that temperature (a choice that is further justified in section 3.3) and (ii) by taking this framework as rigid in the force field. Thus, the framework deformations, if any, are correctly taken into account (since established from experiments) while the force field plays no role on the crystalline structure. The corresponding box size was equal to the lattice spacing $a$ deduced from experiments that are listed in Table 1 together with the number of water molecules used for the simulations $\left(\mathrm{N}_{\mathrm{w}-\mathrm{sim}}\right.$, see section 3.2 for more details). The numbers of framework atoms and extra-framework cations correspond to one unit cell, namely: $\mathrm{Ni}_{18} \mathrm{Na}_{22} \mathrm{Al}_{58} \mathrm{Si}_{134} \mathrm{O}_{384}$. The convergence of the $\mathrm{MC}$ simulations was ensured by carefully avoiding metastable states. ${ }^{37}$ For cations localization, we used the new approach which defines the type of site for each cation based on its local environment (coordination by different oxygen types). ${ }^{37}$ This method can be applied regardless of the local structure of the crystalline framework.

\section{3) RESULTS AND DISCUSSION}

\section{1) Water quantification during stepwise dehydration of $\mathrm{Ni}_{18} \mathrm{Na}_{22} \mathrm{Y}$}

The water content measured by TGA in hydrated $\mathrm{Ni}_{18} \mathrm{Na}_{22} \mathrm{Y}$ (ambient atmosphere) was 27.2 $\mathrm{wt} \%$. This corresponds to about 270 water molecules per unit cell. Part of them are expected to be sensitive to evacuation under secondary vacuum at room temperature (conditions applied at the start of the experiments, see Section 2.2), hence it was necessary to evaluate the 
effect of pumping and to determine the effective water content in $\mathrm{Ni}_{18} \mathrm{Na}_{22} \mathrm{Y}$ when starting the heating phase for neutron diffraction analyses. To this end, the hydrated sample was submitted to two additional TGA done after an evacuation at either $1.33 \times 10^{-2}$ mbar or $4 \times 10^{-6}$ mbar (19.5 and $6.8 \mathrm{wt} \%$ losses, respectively). From these sets of three weight loss measurements and knowing the pressure in the evacuated analysis chamber (estimated at $5.5 \times 10^{-5}$ mbar after stabilization in presence of the sample), the initial water content in $\mathrm{Ni}_{18} \mathrm{Na}_{22} \mathrm{Y}$ in the conditions of patterns recording was found to be $11.3 \mathrm{wt} \%$ (corresponding to 92 water molecules per unit cell).

As soon as heating started and at each subsequent heating step (Figure 1A), water desorption from the zeolite was attested by a pressure increase in the chamber (Figure 1B), a phenomenon that was fruitfully used as preliminary "real time" monitoring of water removal, even if only qualitative (no quantification of desorbed water). Below $200^{\circ} \mathrm{C}$, the pressure profile is quite similar at each step, independently of the temperature range, with a sharp pressure increase when the temperature starts to raise, then a pressure drop followed by a stabilization around $6 \times 10^{-5}$ mbar when the steady temperature is reached. The water removal process thus appears to be regular between room temperature and $200^{\circ} \mathrm{C}$, with no evidence of a temperature at which dehydration would occur predominantly. Moreover, significant dehydration is already seen below $100^{\circ} \mathrm{C}$, it is far to be completed at $120^{\circ} \mathrm{C}$ and is even accentuated at $150^{\circ} \mathrm{C}$, and it continues up to $200^{\circ} \mathrm{C}$. This demonstrates (i) the existence of distinct water adsorption states characterized by distinct adsorption strengths (as further discussed in Section 3.4) and (ii) the presence of strong adsorption sites where some water molecules are still retained at $200^{\circ} \mathrm{C}$ even under vacuum. Above $200^{\circ} \mathrm{C}$, only few water molecules continue to be desorbed (low pressure values compared to previous ones and rapid stabilization at pressures of the order of $10^{-6}$ mbar as expected in the chamber in the absence of any desorption process).

In view of the above-described pressure evolution, neutron diffractograms were recorded during both heating (unstable hydration state) and steady temperature phases (pressure stabilization steps). Figure 2 shows a typical evolution of patterns during heating, taking the $20-40^{\circ} \mathrm{C}$ temperature step as representative example. In this figure, the effect of initial evacuation is also represented. All Bragg peaks in the diffractograms are typical of the FAU structure $^{1}$ and their high intensity and small width indicate high crystallinity. These peaks are superimposed on a background arising from the incoherent scattering on the neutron beam by ${ }^{1} \mathrm{H}$ hydrogen nuclei. From our previous work, these hydrogen atoms in our sample are fully 
attributable to those of the water molecules adsorbed in the zeolite. ${ }^{36-37}$ Accordingly, the incoherent signal significantly decreases upon evacuation (compare curves a and b in Figure 2) and the decrease is accentuated with heating (curve $c$ in Figure 2). Nevertheless, the background level no longer varies as soon as heating stops and it remains stable during the steady temperature step (curves $d$ to $g$ in Figure 2). As already suggested by pressure evolutions, the hydration level thus rapidly reaches a stable state, which brings two important conclusions: (i) each diffractograms recorded at a steady temperature is properly representative of a given (and stable) hydration state and (ii) the decrease of the incoherent signal intensity from one temperature step to another and its overall evolution along heating steps are directly correlated to water removal, giving thus access in real time to residual water quantification depending on temperature.

Such a decrease is illustrated in Figure 3 that shows the evolution of the patterns with steady temperatures. For better signal/noise ratio, all patterns correspond to the average of four (stable) patterns recorded at the given temperature. In Figure 3A, the patterns are reported in a restricted $2 \theta$ range $\left(58-78^{\circ}\right)$ where the intensity of the diffraction peaks is low enough to allow easy visualization of the concomitant background level variations; in Figure 3B, they are shown on a larger $2 \theta$ region, in a $3 \mathrm{D}$ representation mode. In accordance with pressure evolutions, the incoherent signal decreases regularly between 20 and $200^{\circ} \mathrm{C}$, confirming the continuous dehydration of $\mathrm{Ni}_{18} \mathrm{Na}_{22} \mathrm{Y}$ below $200^{\circ} \mathrm{C}$. Then the process slows sharply and it is completed at $350^{\circ} \mathrm{C}$, with no further change of background intensity at $400^{\circ} \mathrm{C}$, neither after cooling to room temperature under vacuum which confirms that the $\mathrm{Ni}_{18} \mathrm{Na}_{22} \mathrm{Y}$ sample remains dehydrated. Knowing the initial water content in the sample before heating (see above), the intensity of the incoherent signal was used to estimate the residual water contents at all steady temperatures $\left(\mathrm{N}_{\mathrm{w}-\text { Inco }}\right.$ in Table 1$)$.

\section{2) $\mathrm{Ni}^{2+}$ and $\mathrm{Na}^{+}$cations locations}

Simultaneous to water content, neutron diffraction informs on structural features, particularly on lattice parameters and cations locations. Whatever the temperature, the diffraction peaks in the patterns are typical of FAU (as in Figure 2) but their positions (Figures 3A) and intensities (Figure 3B) vary with heating, revealing framework distortions and changes in cationic sites occupancies as commonly expected in zeolites. Interestingly, the temperature range between 250 and $300^{\circ} \mathrm{C}$ seems to be critical (associated with drastic changes), while much fewer variations (in peak positions and peak intensities) are seen below $250^{\circ} \mathrm{C}$ and 
above $300^{\circ} \mathrm{C}$, respectively. Hence, the predominant (and regular) dehydration occurring below $200^{\circ} \mathrm{C}$ (as deduced above from pressure and incoherent signal evolutions) has only a very limited impact on the zeolite structure and the major modifications rather take place above $250^{\circ} \mathrm{C}$, when the last few water molecules are removed. Another important point to note is the identical peak positions and intensities at $400^{\circ} \mathrm{C}$ and after cooling down to room temperature (still under vacuum, to avoid rehydration), which reveals that temperature itself has no effect on the structure.

The structures were determined by Rietveld analysis of the patterns at all steady temperatures. Figure 4A shows a representative part of the FAU unit cell where the well-established cationic positions are also represented, identified as site I (at the center of hexagonal prisms), sites I' and II' (inside the sodalite cages) and sites II and III (inside the supercages). From this figure, it is clear that clusters consisting of one sodalite cage and one hexagonal prism allow representing all types of cationic sites. Hence, such type of configuration was chosen to illustrate the framework evolutions and cations migrations identified experimentally along the successive dehydration steps (Figure 4B). On these images, the cations are positioned at sites potentially occupied, as determined by refinement, but without taking into account the distributions between sites (that are detailed in Table 1 together with water contents $\mathrm{N}_{\mathrm{w} \text {-Rietv. }}$ estimated from refinements). Note also that only the $150-400^{\circ} \mathrm{C}$ temperature range is considered because the amount of adsorbed water below $150^{\circ} \mathrm{C}$ is too large to allow proper Rietveld analysis.

From these data, the most remarkable observation is the migration of $\mathrm{Ni}^{2+}$ from sites II and III (in supercages) to more confined sites (I' and II'), with simultaneous exclusion of $\mathrm{Na}^{+}$cations from sodalite cages and hexagonal prisms (all in sites II after heating up to $400^{\circ} \mathrm{C}$ and back to RT). Even if previously suggested, ${ }^{53-54}$ this statement is here unambiguously demonstrated on an experimental basis. In addition, the few water molecules still remaining at low temperature (represented as Ow1 and Ow2 in Figure $4 \mathrm{~B}, 150$ and $250^{\circ} \mathrm{C}$ ) are no longer present at $350^{\circ} \mathrm{C}$, a temperature at which almost all $\mathrm{Ni}^{2+}$ ions have reached confined sites I (Table 1) while $\mathrm{Na}^{+}$ cations have been simultaneously excluded from confined sites I'. This highlights the close relationship between desorption of the last water molecules and cation migration. Nevertheless, a few $\mathrm{Ni}^{2+}$ ions are still found in sites II' after full dehydration (clusters $350^{\circ} \mathrm{C}$ and Back to RT in Figure 3B and data in Table 1) due to the fact that all sites I are already populated (only 16 sites I per unit cell for $18 \mathrm{Ni}^{2+}$ ). 
Figure 5 compares, as a function of temperature, the evolution of the numbers of $\mathrm{Na}^{+}$(Figure 5A) and $\mathrm{Ni}^{2+}$ (Figure 5B) cations in each type of FAU cationic crystallographic sites as estimated from experiments (full lines) and from Monte Carlo simulations (dotted lines). While experiments provide mean values on observables, modeling can give more precise molecular descriptions. As explained in Section 2, the model used in the simulations considers the framework as rigid, hence the deformation occurring upon (de)hydration had to be taken into account. To this end, we used at each studied temperature the framework coordinates (for more details, see CIF files with depository numbers referenced in Section 2.4) and a water content value $\mathrm{N}_{\mathrm{w}-\mathrm{Sim}}$ similar to that deduced from refinement $\left(\mathrm{N}_{\mathrm{w}-\text { Rietv }}\right.$ values in Table 1 that also agree with $\mathrm{N}_{\mathrm{w}-\text { Inco }}$ values at all temperatures).

A very good agreement is globally observed between experimental and simulated cations locations. Two apparent disagreements deserve, however, to be discussed. Firstly, at $150^{\circ} \mathrm{C}$, $\mathrm{Na}^{+}$is predominantly found either in sites I' (according to experiments) or in sites I (according to simulations). In fact, as illustrated in Figure 6, the site identified by Rietveld analysis is a delocalized one with respect to a "true" site I (expected at the center of the hexagonal prism), and it is close (within $1 \AA$ ) to sites classically referred to as sites I' (positioned in proximity of the center of the 6-membered ring widows between the sodalite cage and the prism). We already reported similar delocalization of site $\mathrm{I}$ for $\mathrm{K}^{+}$or $\mathrm{Ni}^{2+}$ on comparable systems as deduced from EXAFS, X-ray or DFT data. ${ }^{35,38,41}$ Therefore, there is no contradiction between experimental and simulated results in this case. Secondly, as already noted above, some $\mathrm{Ni}^{2+}$ cations are experimentally found in site $\mathrm{II}^{\prime}$ at $350^{\circ} \mathrm{C}$ (due to the nickel content slightly higher than that of hexagonal prisms), but the simulation rather assigns these cations to sites II. This discrepancy can be understood by considering sites II' as an intermediate position between sites II (where Ni is positioned at low temperature) and I (after dehyadration) during nickel migration towards hexagonal prisms. It is worth adding that the low site II' occupancy is in accordance with a former X-ray single crystal structure study on a dehydrated nickel-exchanged natural Y zeolite of composition $\mathrm{Ni}_{27} \mathrm{Ca}_{4} \mathrm{Si}_{134} \mathrm{Al}_{58} \mathrm{O}_{384}$ by Olson ${ }^{55}$ and with results from Rietveld refinements on synthetic $\mathrm{Y}$ zeolites of compositions $\mathrm{Ni}_{14} \mathrm{Na}_{23} \mathrm{H}_{5} \mathrm{Si}_{136} \mathrm{Al}_{56} \mathrm{O}_{384},{ }^{54}$ $\mathrm{Ni}_{21} \mathrm{Na}_{17} \mathrm{Si}_{133} \mathrm{Al}_{59} \mathrm{O}_{384},{ }^{56} \quad \mathrm{Ni}_{30} \mathrm{Na}_{7} \mathrm{Cl}_{12} \mathrm{Si}_{137} \mathrm{Al}_{55} \mathrm{O}_{384},{ }^{57}$ and $\mathrm{Ni}_{19.8} \mathrm{Na}_{19.6} \mathrm{Al}_{55} \mathrm{Si}_{137} \mathrm{O}_{384},{ }^{44}$ respectively. The fact that it is an intermediate state could explain the absence of identification of such environment by simulations.

Apart from these minor differences, all trends found by the simulations confirm those from experiments, namely: (i) at $150^{\circ} \mathrm{C}, \mathrm{Ni}^{2+}$ is mainly positioned in sites II (and to a lesser extent 
$\left.\mathrm{I}^{\prime}\right)$, (ii) the migration is predominant between $250^{\circ} \mathrm{C}$ and $350^{\circ} \mathrm{C}$, consisting in the displacement of nickel ions towards more confined sites I (and sites II-II' once sites I are fully populated) and (iii) $\mathrm{Na}^{+}$ions are simultaneously expelled from sites I' (close to sites I) because of steric constraints and of electrostatic repulsion, hence they migrate towards sites II. All these data demonstrate the high affinity of bare divalent nickel ions for sites I. Moreover, this affinity governs not only the location of nickel and its migration upon (de)hydration, but also that of sodium (as further discussed in Section 3.4).

Finally, it is worth adding, with respect to sites III (an expected location of the hexahydrate $\mathrm{Ni}^{2+}$ clusters in fully hydrated FAU), ${ }^{58}$ that their low occupancy agrees with the fact that many water molecules were already removed at $150^{\circ} \mathrm{C}$ (about $60 \%$ compared to water content after evacuation), nickel ions being therefore no longer in a bulky hexahydrate environment.

\section{3) Crystalline framework deformation}

Upon temperature changes, the crystalline zeolite structure evolves as well, characterized by an overall framework contraction (lattice parameter decreasing from $24.7 \AA$ at $20^{\circ} \mathrm{C}$ to $24.4 \AA$ at $400^{\circ} \mathrm{C}$, Figure $7 \mathrm{~A}$ ) that is concomitant with $\mathrm{Ni}^{2+}$ cations displacements from sites II towards more confined sites I (Figure 7C). Again, this phenomenon does not take place during the predominant $25-250^{\circ} \mathrm{C}$ dehydration steps but only at temperatures above $250^{\circ} \mathrm{C}$ when the last few water molecules are removed (Figure $7 \mathrm{~B}$ and $\mathrm{N}_{\mathrm{w} \text {-Rietv }}$ and $\mathrm{N}_{\mathrm{w} \text {-Inco }}$ values in Table 1). Moreover, the contraction of the structure reached at $400^{\circ} \mathrm{C}$ remains after bringing dehydrated $\mathrm{Ni}_{18} \mathrm{Na}_{22} \mathrm{Y}$ back to room temperature (as already noted in Section 3.2, see also data in Table 1). This set of observations demonstrates that the decrease in the lattice parameter is definitively neither due to a temperature effect nor associated to a progressive release of water from the cages; it is rather intimately related to the migration of $\mathrm{Ni}^{2+}$ toward sites I (as previously proposed by Gallezot et al. ${ }^{53}$ ) that occurs in a narrow temperature range and is concomitant to the desorption of the last water molecules.

In addition to the global contraction, we also observe a local distortion of the hexagonal prism (Figure 8) which is coupled with the above-mentioned shift of sites I with respect to the centre of the prism. The simple force field used in the present study is not able to capture, by itself, this local deformation induced by cationic sites delocalization. Nevertheless, the importance of taking it into account, and therefore to consider an appropriate structure at each temperature to obtain relevant simulations, can be stressed out. This is demonstrated by the cationic 
distributions reported in the last line of Table 1: in this simulation, water was not considered (aiming at simulating a dehydrated state) but the framework taken for simulation was the "starting" experimental one (measured at $150^{\circ} \mathrm{C}$ on a partially hydrated sample). Clearly, the simulation in such case does not correctly reproduce the cations distribution since both $\mathrm{Ni}^{2+}$ and $\mathrm{Na}^{+}$distributions are quite balanced between sites I and II, in place of positioning $\mathrm{Ni}^{2+}$ cations predominantly in sites I and $\mathrm{Na}^{+}$cations in sites II as was deduced from both (i) experiments at the dehydrated state and (ii) simulations done by considering the appropriate dehydrated structure (data in line 1 of Table 1). This underlines the impact of the framework deformation on the cations locations (and vice versa), both being intimately related to water release or uptake upon (de)-hydration as further discussed below.

For the sake of completion, it can be added that diffraction only provides an average picture of the structure, which reflects all components of the system (including empty cationic sites). Nevertheless, the hexagonal prisms (sites I and I'), which are the most prone to deformation upon migration of nickel cations, are never empty (see Table 1), being either occupied by sodium at low temperature (high water content) or fully occupied by nickel at high temperature (low water content). Therefore the established average structures and the observed deformations give correct representations of the local structure of individual (sodium-filled or nickel-filled) hexagonal prisms. Hence, even if not as accurate as more elaborate force fields or ab initio calculations, the present methodology is able to provide, in a rather simple way, correct description of subtle features of a complex system.

\section{4) Water and cation localization upon (de)hydration}

Since water molecules are experimentally not easy to localize with high precision, the following analysis is based on the molecular simulations only only. However, the good agreement with experiments for cation localization (including non-trivial features described above) and the water molecules seen at $150^{\circ} \mathrm{C}$ and $250^{\circ} \mathrm{C}$ in Figure $4 \mathrm{~B}$ (Ow1 and $\mathrm{Ow} 2$ ) support the relevance of this discussion.

In the presence of water, divalent $\mathrm{Ni}^{2+}$ cations tend to hydrate due to strong electrostatic interactions with water. Since water molecules are exclusively found in sodalite cages and supercages (due to steric constraints), these interactions can only take place if the cations are placed in sites compatible with the presence of water molecules. In turn, the location of hydrated $\mathrm{Ni}^{2+}$ cations also imposes constraints on the other $\mathrm{Ni}^{2+}$ and $\mathrm{Na}^{+}$cations due to the strong electrostatic repulsion between them. In the range of experimental water contents 
under study, the radial distribution functions (rdf, not shown) demonstrate that water molecules only coordinate $\mathrm{Ni}^{2+}$ cations (Ni-O distance $\sim 2.3 \AA$ ) whereas $\mathrm{Na}^{+}$cations are free of water (Na-O distance $\sim 5.3 \AA$, too long for a coordination state). The integral of the rdfs further provide the coordination numbers with, on average, one water molecule per $\mathrm{Ni}^{2+}$ cation for the higher experimental water content (i.e $\sim 17$ water molecules at $150^{\circ} \mathrm{C}$ ). The evolution of the number of molecules per unit cell in sodalite cages and supercages as a function of temperature is shown in Figure 9.

At $150^{\circ} \mathrm{C}$, the approximately equal numbers of water molecules (8-9) in both types of cages contrast with that of $\mathrm{Ni}^{2+}$ cations (13 in supercages and 5 in sodalites). In order to clarify this feature, we analyzed in more detail the joint distributions of cations and water species using two measures. On the one hand, for each individual sodalite cage or supercage, we computed the probability $\mathrm{P}_{\text {cage }}\left(\mathrm{N}_{\mathrm{Na}}, \mathrm{N}_{\mathrm{Ni}}, \mathrm{N}_{\mathrm{w}}\right)$ to contain simultaneously $\mathrm{N}_{\mathrm{Na}}$ sodium cations, $\mathrm{N}_{\mathrm{Ni}}$ nickel cations and $\mathrm{N}_{\mathrm{w}}$ water molecules. This led us to the conclusion that a given cage never contains more than one cation. On the other hand, for each type of site occupied by $\mathrm{Ni}^{2+}$ cations, we determined the probability $\mathrm{P}_{\text {site }}\left(\mathrm{N}^{\text {sod }}, \mathrm{N}^{\text {sup }}\right)$ to be coordinated simultaneously by $\mathrm{N}^{\text {sod }}$ water molecules in sodalite cages (which can accommodate only up to 4 water molecules) and by $\mathrm{N}^{\text {sup }}$ water molecules in supercages. This allowed us to identify the most probable environments for nickel cations and the associated water molecules (Figure 10). As a whole, nickel cations are mostly hydrated either in sites I', by a single water molecule in a sodalite cage $\left(\mathrm{SI}^{\prime}-\mathrm{W}^{\mathrm{sod}}\right)$, or in sites II, by one molecule in a sodalite cage $\left(\mathrm{SII}-\mathrm{W}^{\mathrm{sod}}\right)$ or in a supercage $\left(\mathrm{SII}-\mathrm{W}^{\text {sup }}\right)$. Less frequently, configurations with simultaneous coordination by one molecule in a sodalite cage and another in a supercage are observed (SII-W ${ }^{\text {both }}$ ). Finally, one should note that not all cations in such sites are hydrated (SI'-noW and SII-noW). The number of $\mathrm{Ni}^{2+}$ cations per unit cell in such environments is reported as a function of water content in Table 2. Note that many other microscopic arrangements are possible, each contributing only to a minor fraction but adding up to $20-30 \%$ of the total configurations. Together with the sodium cation distributions of Table 1 , these results provide a consistent picture of the evolution of cations along the dehydration process.

For the largest water content (at $150^{\circ} \mathrm{C}$ ), most of the $18 \mathrm{Ni}^{2+}$ cations are hydrated by one water molecule, either in sites II ( 3 SII-W ${ }^{\text {sod }}, 5$ SII-W ${ }^{\text {sup }}, 1$ SII-W ${ }^{\text {both }}$ and 4 SII-noW) or in sites I' (3 $\mathrm{SI}^{\prime}-\mathrm{W}^{\text {sod }}$ and 2 SI'-noW), while (non hydrated) $\mathrm{Na}^{+}$cations occupy mainly sites II (13) and half of the most confined sites, i.e. sites I (8). As temperature increases to $200^{\circ} \mathrm{C}$, then $250^{\circ} \mathrm{C}$, the departure of water $\left(6\right.$ water molecules per unit cell at $\left.250^{\circ} \mathrm{C}\right)$ is associated with the migration of 
$\mathrm{Ni}^{2+}$ cations from sites II towards sites I' (the number of hydrated $\mathrm{Ni}^{2+}$ cations in both types of sites decreasing, as expected). At that temperature, half of sites I are still occupied by $\mathrm{Na}^{+}$ cations, but the temperature is not yet high enough to allow full water desorption and nickel migration towards non-occupied confined sites I. This significant reorganization only takes places between 250 and $300^{\circ} \mathrm{C}$, afterwards sites I are fully populated with (dehydrated) $\mathrm{Ni}^{2+}$ cations, which induces, in turn, the full displacement of $\mathrm{Na}^{+}$cations toward sites II.

The migration of $\mathrm{Ni}^{2+}$ cations toward more accessible sites in the presence of water indicates that the interaction of these ions with water is stronger than with the zeolite framework. To further confirm this tendency, we also performed a simulation considering a water content much larger than the experimental one (114 molecules per unit cell). In this highly hydrated situation, hydrated $\mathrm{Ni}^{2+}$ cations lay in the more accessible sites (including $11 \mathrm{Ni}^{2+}$ in site II and $2 \mathrm{Ni}^{2+}$ in site III), while $\mathrm{Na}^{+}$cations occupy the remaining available sites (on average 4.5 $\mathrm{Na}^{+}$in site I, $6.5 \mathrm{Na}^{+}$in site I', $9 \mathrm{Na}^{+}$in site II and $2 \mathrm{Na}^{+}$in site III). In the dry state, the interaction with the framework is maximized not only by shifting toward more confined sites, into the hexagonal prism, but also by deforming it, as already discussed in Section 3.3 and reported in a molecular simulation study of $\mathrm{Na}_{16} \mathrm{Co}_{40} \mathrm{X}$ faujasite. ${ }^{34}$ Overall, the present study illustrates the complex interplay between cation hydration, cation location and framework deformation, in particular for multivalent ions.

\section{CONCLUSION}

Upon heating from room temperature up to $400^{\circ} \mathrm{C}$, Ni-exchanged $\mathrm{NaY}$ faujasite zeolites undergo a series of structural rearrangements involving dehydration, cation redistribution and framework deformation. In the present work, we have characterized the various steps in details by a new approach combining neutron diffraction and classical molecular simulations. On the one hand, the diffraction patterns allow monitoring the zeolite structure and the average cation location depending on the temperature, but also the water content that is quantified in real time from the incoherent signal. On the other hand, molecular simulations provide insights into the correlations between the positions of cations and water molecules. Importantly, the dehydration process is progressive between 20 and $200^{\circ} \mathrm{C}$, whereas the migration of $\mathrm{Ni}^{2+}$ toward highly confined sites takes place only above $250^{\circ} \mathrm{C}$ together with the removal of the last few water molecules. Importantly, this cation displacement is closely correlated with a unit cell contraction associated, in turn, with a strong deformation of the 
hexagonal prism where the $\mathrm{Ni}^{2+}$ cation is hosted. On the contrary, temperature by itself does not play any role in this deformation.

Several strategies can be envisioned to improve the microscopic model used in the present work. In principle, it would be desirable to use DFT calculations to circumvent the use of classical force fields. Despite their own limitations (choice of the functional, basis set, etc), such calculations provide to date the most accurate description of interactions between atoms. Nevertheless, as underlined in Section 2.5, they currently do not allow full unit cell description, in particular in the presence of water. Moreover, they do not allow a proper sampling of relevant configurations at finite temperature, which requires generating enough statistically independent configurations by molecular dynamics or Monte Carlo simulations. Therefore, in the near future, it may be easier to overcome the limitations of the present model by improving classical force fields.

A first obvious step in this direction would be to differentiate $\mathrm{Si}$ and $\mathrm{Al}$ atoms, which have been treated here as average $\mathrm{T}$ atoms. While such a distinction has been shown to play a minor role when only sodium cations are present, ${ }^{59}$ it may be more important in the presence of divalent nickel cations. We are currently investigating this possibility. More importantly, the present work underlines the importance of taking structural changes into consideration. This highlights the need for classical force fields able to estimate the framework flexibility when considering various hydration conditions, in particular in the presence of multivalent ions. The recent developments of a polarizable force field for similar alumino-silicates, namely clay minerals, should benefit the present case of zeolites. ${ }^{60-61}$

\section{ACKNOWLEDGEMENTS}

WL acknowledges financial support (PhD grant) from Région Ile-de-France via the DIM OXYMORE. Gilles André is sincerely thanked for his efficient help on neutron scattering experiments. All authors are grateful to LLB for the beamtime allocated on G4.1 


\section{REFERENCES}

1. Baerlocher, C.; McCusker, L. B., Database of Zeolite Structures. http://www.izastructure.org/databases/.

2. Goursot, A.; Coq, B.; Fajula, F., Toward a Molecular Description of Heterogeneous Catalysis: Transition Metal Ions in Zeolites. J. Catal. 2003, 216, 324-332.

3. Nachtigall, P.; Delgado, M. R.; Nachtigallova, D.; Arean, C. O., The Nature of Cationic Adsorption Sites in Alkaline Zeolites-Single, Dual and Multiple Cation Sites. PCCP 2012, 14, 1552-1569.

4. Zaarour, M.; Dong, B.; Naydenova, I.; Retoux, R.; Mintova, S., Progress in Zeolite Synthesis Promotes Advanced Applications. Microporous Mesoporous Mater. 2014, 189, 11-21.

5. Barrer, R. M.; Townsend, R. P., Ion-Exchange Equilibria in Zeolites and Clay Minerals. Different Concentration Scales and Derived Thermodynamic Functions. J. Chem. Soc., Faraday Trans. 2 1984, 80, 629-640.

6. Breck, D. W.; Flanigen, E. M., Synthesis and Properties of Union Carbide zeolites L, X, and Y. In Molecular Sieves; Society of Chemical Industry: London, 1968; pp 47-61.

7. Frising, T.; Leflaive, P., Extraframework Cation Distributions in $\mathrm{X}$ and $\mathrm{Y}$ faujasite Zeolites: A Review. Microporous Mesoporous Mater. 2008, 114, 27-63.

8. Armor, J. N., Metal-Exchanged Zeolites as Catalysts. Microporous Mesoporous Mater. 1998, 22, 451-456.

9. Brandenberger, S.; Kröcher, O.; Tissler, A.; Althoff, R., The State of the Art in Selective Catalytic Reduction of $\mathrm{NO}_{\mathrm{x}}$ by Ammonia Using Metal-Exchanged Zeolite Catalysts. Cat. Rev. - Sci. Eng. 2008, 50, 492-531.

10. Gao, F.; Kwak, J. H.; Szanyi, J.; Peden, C. H. F., Current Understanding of CuExchanged Chabazite Molecular Sieves for Use as Commercial Diesel Engine $\mathrm{DeNO}_{\mathrm{x}}$ Catalysts. Top. Catal. 2013, 56, 1441-1459.

11. Musi, A.; Massiani, P.; Brouri, D.; Trichard, J.-M.; Da Costa, P., On the Characterisation of Silver Species for SCR of $\mathrm{NO}_{\mathrm{x}}$ with Ethanol. Catal. Lett. 2009, 128, 25-30.

12. Mihaylov, M.; Hadjiivanov, K.; Panayotov, D., FTIR Mechanistic Studies on the Selective Catalytic Reduction of $\mathrm{NO}_{\mathrm{x}}$ with Methane over Ni-Containing Zeolites: Comparison between NiY and Ni-ZSM-5. Applied Catalysis B: Environmental 2004, 51, $33-42$.

13. Esquivel, D.; Cruz-Cabeza, A. J.; Jiménez-Sanchidrián, C.; Romero-Salguero, F. J., Transition Metal Exchanged $\beta$ Zeolites: Characterization of the Metal State and Catalytic 
Application in the Methanol Conversion to Hydrocarbons. Microporous Mesoporous Mater. 2013, 179, 30-39.

14. Kazansky, V. B., State and Properties of Ion-Exchanged Cations in Zeolites: 2. IR Spectra and Chemical Activation of Adsorbed methane. Kinet. Catal. 2014, 55, 737-747.

15. Berthomieu, D.; Delahay, G., Recent Advances in $\mathrm{Cu}^{\mathrm{I} / \mathrm{I}} \mathrm{Y}$ : Experiments and Modeling. Cat. Rev. - Sci. Eng. 2006, 48, 269-313.

16. McMillan, S. A.; Snurr, R. Q.; Broadbelt, L. J., Interaction of Divalent Metal Cations with Ferrierite: Insights from Density Functional Theory. Microporous Mesoporous Mater. 2004, 68, 45-53.

17. Dedecek, J.; Sobalik, Z.; Tvaruazkova, Z.; Kaucky, D.; Wichterlova, B., Coordination of $\mathrm{Cu}$ Ions in High-Silica Zeolite Matrixes. $\mathrm{Cu}^{+}$Photoluminescence, IR of NO Adsorbed on $\mathrm{Cu}^{2+}$, and $\mathrm{Cu}^{2+}$ ESR Study. J. Phys. Chem. 1995, 99, 16327-16337.

18. Pierloot, K.; Delabie, A.; Groothaert, M. H.; Schoonheydt, R. A., A Reinterpretation of the EPR Spectra of $\mathrm{Cu}(\mathrm{II})$ in Zeolites A, Y and ZK4, Based on ab initio Cluster Model Calculations. PCCP 2001, 3, 2174-2183.

19. Rejmak, P.; Sierka, M.; Sauer, J., Theoretical Studies of $\mathrm{Cu}(\mathrm{I})$ Sites in Faujasite and Their Interaction with Carbon Monoxide. PCCP 2007, 9, 5446-5456.

20. Aleksandrov, H. A.; Vayssilov, G. N., Theoretical Investigation of Ethane Dehydrogenation on Cationic Zn Species in ZSM-5 Zeolites-The Second Al Center in Vicinity of the Cation is Essential for the Accomplishment of the Complete Catalytic Cycle. Catal. Today 2010, 152, 78-87.

21. Beauvais, C.; Boutin, A.; Fuchs, A. H., A Numerical Evidence for Nonframework Cation Redistribution Upon Water Adsorption in Faujasite Zeolite. ChemPhysChem 2004, 5, 1791-1793.

22. Sobalík, Z.; Dědeček, J.; Kaucký, D.; Wichterlová, B.; Drozdová, L.; Prins, R., Structure, Distribution, and Properties of Co Ions in Ferrierite Revealed by FTIR, UV-Vis, and EXAFS. J. Catal. 2000, 194, 330-342.

23. Schoonheydt, R. A., Transition Metal Ions in Zeolites: Siting and Energetics of $\mathrm{CU}^{2+}$. Cat. Rev. - Sci. Eng. 1993, 35, 129-168.

24. Delahay, G.; Ayala Villagomez, E.; Ducere, J.-M.; Berthomieu, D.; Goursot, A.; Coq, B., Selective Catalytic Reduction of $\mathrm{NO}$ by $\mathrm{NH}_{3}$ on $\mathrm{Cu}$-Faujasite Catalysts: An Experimental and Quantum Chemical Approach. ChemPhysChem 2002, 3, 686-692. 
25. Groust, J.-F.; Pommier, C.; Stievano, L.; Villain, F.; Giorgetti, C.; Baudelet, F.; Massiani, P., Real Time Monitoring of the Evolution of $\mathrm{Ni}^{2+}$ Environment in Faujasite upon Rehydration by in situ Dispersive-EXAFS. Catal. Lett. 2005, 102, 257-260.

26. Mortier, W. J.; Van den Bossche, E.; Uytterhoeven, J. B., Influence of the Temperature and Water Adsorption on the Cation Location in Na-Y Zeolites. Zeolites 1984, 4, 41-44.

27. Abrioux, C.; Coasne, B.; Maurin, G.; Henn, F.; Boutin, A.; Di Lella, A.; Nieto-Draghi, C.; Fuchs, A. H., A Molecular Simulation Study of the Distribution of Cation in Zeolites. Adsorption 2008, 14, 743-754.

28. Di Lella, A.; Desbiens, N.; Boutin, A.; Demachy, I.; Ungerer, P.; Bellat, J.-P.; Fuchs, A. H., Molecular Simulation Studies of Water Physisorption in Zeolites. PCCP 2006, 8, 5396-5406.

29. Jeffroy, M.; Borissenko, E.; Boutin, A.; Di Lella, A.; Porcher, F.; Souhassou, M.; Lecomte, C.; Fuchs, A. H., Evidence of a Framework Induced Cation Redistribution upon Water Adsorption in Cobalt Exchanged X Faujasite Zeolite: A Joint Experimental and Simulation Study. Microporous Mesoporous Mater. 2011, 138, 45-50.

30. Rotenberg, B.; Marry, V.; Vuilleumier, R.; Malikova, N.; Simon, C.; Turq, P., Water and Ions in Clays: Unraveling the Interlayer/Micropore Exchange Using Molecular Dynamics. Geochim. Cosmochim. Acta 2007, 71, 5089-5101.

31. Marry, V.; Rotenberg, B.; Turq, P., Structure and Dynamics of Water at a Clay Surface from Molecular Dynamics Simulation. PCCP 2008, 10, 4802-4813.

32. Rotenberg, B.; Morel, J.-P.; Marry, V.; Turq, P.; Morel-Desrosiers, N., On the Driving Force of Cation Exchange in Clays: Insights from Combined Microcalorimetry Experiments and Molecular Simulation. Geochim. Cosmochim. Acta 2009, 73, 4034-4044.

33. Rotenberg, B.; Marry, V.; Malikova, N.; Turq, P., Molecular Simulation of Aqueous Solutions at Clay Surfaces. J. Phys.: Condens. Matter 2010, 22, 284114.

34. Jeffroy, M.; Boutin, A.; Fuchs, A. H., Understanding the Equilibrium Ion Exchange Properties in Faujasite Zeolite from Monte Carlo Simulations. J. Phys. Chem. B 2011, $115,15059-15066$.

35. Guesmi, H.; Massiani, P., A Combined EXAFS and DFT Study of the $\mathrm{Ni}^{2+}$ Environment in Dehydrated Ni/NaX. Catal. Today 2011, 177, 25-30.

36. Porcher, F.; Paillaud, J.-L.; Gaberova, L.; Andre, G.; Casale, S.; Massiani, P., Monitoring by in situ Neutron Diffraction of Simultaneous Dehydration and $\mathrm{Ni}^{2+}$ Mobility in Partially Exchanged NaY Zeolites. New J. Chem. 2016, 40, 4228-4235. 
37. Louisfrema, W.; Rotenberg, B.; Porcher, F.; Paillaud, J.-L.; Massiani, P.; Boutin, A., Cation Redistribution upon Dehydration of $\mathrm{Na}_{58} \mathrm{Y}$ Faujasite Zeolite: A Joint Neutron Diffraction and Molecular Simulation Study. Mol. Simul. 2015, 41, 1371-1378.

38. Guesmi, H.; Costa, D.; Berthomieu, D.; Massiani, P., Nickel Coordination to Lattice Oxygens in Basic LSX, X and Y Sodium Faujasites: A DFT Study. J. Phys. Chem. C 2011, 115, 5607-5618.

39. Moulin, B.; Oliviero, L.; Maugé, F.; Groust, J.-F.; Krafft, J.-M.; Costentin, G.; Massiani, P., Probing the Strength, Concentration and Environment of Basic Sites in Zeolites by IR Spectroscopy. In Stud. Surf. Sci. Catal.; Gédéon, A.; Massiani, P.; Babonneau, F., Eds.; Elsevier: 2008; Vol. 174, Part B, pp 861-864.

40. Barthomeuf, D., Si,Al Ordering and Basicity Clusters in Faujasites. J. Phys. Chem. B 2005, 109, 2047-2054.

41. Guesmi, H.; Massiani, P.; Nouali, H.; Paillaud, J.-L., A Combined Experimental and Theoretical Study of the Simultaneous Occupation of SIa and SI' sites in Fully Dehydrated K-LSX. Microporous Mesoporous Mater. 2012, 159, 87-95.

42. Marti', J.; Soria, J.; Cano, F. H., Cation Location in Hydrated NaY Zeolites. J. Colloid Interface Sci. 1977, 60, 82-86.

43. Thomas, J. M.; Williams, C.; Rayment, T., Monitoring Cation-Site Occupancy of NickelExchanged Zeolite Y Catalysts by High-Temperature in situ X-Ray Powder Diffractometry. J. Chem. Soc., Faraday Trans. 1 1988, 84, 2915-2931.

44. Dooryhee, E.; Catlow, C. R. A.; Couves, J. W.; Maddox, P. J.; Thomas, J. M.; Greaves, G. N.; Steel, A. T.; Townsend, R. P., A Study of Cation Environment and Movement during Dehydration and Reduction of Nickel-Exchanged Zeolite Y by X-Ray Absorption and Diffraction. J. Phys. Chem. 1991, 95, 4514-4521.

45. Seo, S. M.; Lim, W. T.; Seff, K., Single-Crystal Structures of Fully and Partially Dehydrated Zeolite Y (FAU, Si/Al $=1.56) \mathrm{Ni}^{2+}$ Exchanged at a Low pH, 4.9. J. Phys. Chem. C 2012, 116, 13985-13996.

46. Kim, C. W.; Jung, K. J.; Heo, N. H.; Kim, S. H.; Hong, S. B.; Seff, K., Crystal Structures of Vacuum-Dehydrated $\mathrm{Ni}^{2+}$-Exchanged Zeolite $\mathrm{Y}(\mathrm{FAU}, \mathrm{Si} / \mathrm{Al}=1.69)$ Containing Three-Coordinate $\mathrm{Ni}^{2+}, \mathrm{Ni}_{8} \mathrm{O}_{4} \cdot \mathrm{xH}_{2} \mathrm{O}^{8+}, \mathrm{x} \leq 4$, Clusters with Near Cubic $\mathrm{Ni}_{4} \mathrm{O}_{4}$ Cores, and $\mathrm{H}^{+}$. J. Phys. Chem. C 2009, 113, 5164-5181.

47. Larson, A. C.; Von Dreele, R. B. General Structure Analysis System (GSAS), Los Alamos National Laboratory Report LAUR 86-748: 2004. 
48. Toby, B., EXPGUI, a Graphical User Interface for GSAS. J. Appl. Crystallogr. 2001, 34, 210-213.

49. Jaramillo, E.; Auerbach, S. M., New Force Field for Na Cations in Faujasite-Type Zeolites. J. Phys. Chem. B 1999, 103, 9589-9594.

50. Dang, L. X., Mechanism and Thermodynamics of Ion Selectivity in Aqueous Solutions of 18-Crown-6 Ether: A Molecular Dynamics Study. J. Am. Chem. Soc. 1995, 117, 69546960.

51. Jorgensen, W. L.; Chandrasekhar, J.; Madura, J. D.; Impey, R. W.; Klein, M. L., Comparison of Simple Potential Functions for Simulating Liquid Water. J. Chem. Phys. 1983, 79, 926-935.

52. Buttefey, S.; Boutin, A.; Fuchs, A. H., Cation Distribution in Faujasite-Type Zeolites: A Test of Semi-Empirical Force Fields for Na Cations. Mol. Simul. 2002, 28, 1049-1062.

53. Gallezot, P.; Ben Taarit, Y.; Imelik, B., X-Ray Diffraction Study of Nickel Ion Migration in Y-Zeolite. J. Catal. 1972, 26, 481-483.

54. Gallezot, P.; Imelik, B., Location of Nickel Ions in Y Zeolites. I. Influence of Thermal Treatment and Exchange Level on Nickel Positions. J. Phys. Chem. 1973, 77, 652-656.

55. Olson, D. H., Crystal Structure of the Zeolite Nickel Faujasite. J. Phys. Chem. 1968, 72, 4366-4373.

56. Couves, J. W.; Jones, R. H.; Thomas, J. M.; Smith, B. J., Charting Cation Migration in a Nickel exchanged Zeolitic Catalyst: An in situ Rietveld X-Ray Study. Adv. Mater. 1990, $2,181-183$

57. Haniffa, R. M.; Seff, K., Partial Structures of Fully Dehydrated $\mathrm{Ni}_{30} \mathrm{Na}_{7} \mathrm{Cl}_{12} \mathrm{Si}_{137} \mathrm{Al}_{55} \mathrm{O}_{384}$ (Solid-State Nickel(II)-Exchanged Zeolite $\mathrm{Y}$ ) and of Its $\mathrm{D}_{2} \mathrm{O}$ Sorption Complex by Pulsed-Neutron Diffraction. J. Phys. Chem. B 1998, 102, 2688-2695.

58. Maxwell, I. E.; De Boer, J. J., Crystal Structures and Dehydrated Divalent-CopperExchanged Faujasite. J. Phys. Chem. 1975, 79, 1874-1879.

59. Mellot-Draznieks, C.; Buttefey, S; Boutin, A.; Fuchs, A. H. Placement of cations in NaX faujasite-type zeolite using (N,V,T) Monte Carlo simulations. Chem. Comm. 2001, 2200-2201.

60. Tazi, S.; Molina, J. J.; Rotenberg, B.; Turq, P.; Vuilleumier, R.; Salanne, M., A Transferable ab initio Based Force Field for Aqueous Ions. J. Chem. Phys. 2012, 136, 114507.

61. Tesson, S.; Salanne, M.; Rotenberg, B.; Tazi, S.; Marry, V., Classical Polarizable Force Field for Clays: Pyrophyllite and Talc. J. Phys. Chem. C 2016, 120, 3749-3758. 
Table 1. Structural characteristics of the $\mathrm{Ni}_{18} \mathrm{Na}_{22} \mathrm{Y}$ faujasite sample at the studied temperatures: (i) lattice parameter $(a)$, (ii) experimental ( $\mathrm{N}_{\mathrm{w}-\text { Inco }}$ and $\left.\mathrm{N}_{\mathrm{w}-\mathrm{Rietv}}\right)$ and theoretical $\left(\mathrm{N}_{\mathrm{w}-\mathrm{Sim}}\right)$ number of water molecules per unit cell and (iii) number of $\mathrm{Na}^{+}$and $\mathrm{Ni}^{2+}$ cations per unit cell in the different types of cationic crystallographic sites (and total number) as estimated experimentally (Exp) or by Monte Carlo simulations (Sim). The estimated standard deviations are indicated in brackets.

\begin{tabular}{|c|c|c|c|c|c|c|c|c|c|c|c|c|c|c|c|c|c|c|c|c|c|c|c|c|}
\hline \multirow{4}{*}{ 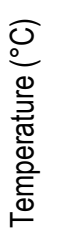 } & \multirow{2}{*}{\multicolumn{3}{|c|}{$\begin{array}{l}\text { Water content } \\
\text { (molecules/u.c.) }\end{array}$}} & \multirow{4}{*}{$a(\AA ̊ A) b$} & \multicolumn{4}{|c|}{ Site I } & \multicolumn{4}{|c|}{ Site I' } & \multicolumn{4}{|c|}{ Site II } & \multicolumn{4}{|c|}{ Site III } & \multicolumn{4}{|c|}{ Total } \\
\hline & & & & & \multicolumn{2}{|c|}{$\mathrm{Na}^{+}-\mathrm{I}$} & \multicolumn{2}{|c|}{$\mathrm{Ni}^{2+}-\mathrm{I}$} & \multicolumn{2}{|c|}{$\mathrm{Na}^{+} \mathrm{II}^{\prime}$} & \multicolumn{2}{|c|}{$\mathrm{Ni}^{2+} \mathrm{Il}^{\prime}$} & \multicolumn{2}{|c|}{$\mathrm{Na}^{+}-\mathrm{II}$} & \multicolumn{2}{|c|}{$\mathrm{Ni}^{2+}-\mathrm{II}$} & \multicolumn{2}{|c|}{$\mathrm{Na}^{+}-\mathrm{III}$} & \multicolumn{2}{|c|}{$\mathrm{Ni}^{2+}-\mathrm{III}$} & \multicolumn{2}{|c|}{ Total $\mathrm{Na}^{+}$} & \multicolumn{2}{|c|}{ Total $\mathrm{Ni}^{2+}$} \\
\hline & \multicolumn{2}{|c|}{ Exp. } & \multirow{2}{*}{$\frac{\text { Sim. }}{N_{\text {w-Sim }}}$} & & \multirow{2}{*}{ Exp. } & \multirow[t]{2}{*}{ Sim. } & \multirow{2}{*}{ Exp. } & \multirow[t]{2}{*}{ Sim. } & \multirow{2}{*}{ Exp. } & \multirow[t]{2}{*}{ Sim. } & \multirow[t]{2}{*}{ Exp. } & \multirow[t]{2}{*}{ Sim. } & \multirow[t]{2}{*}{ Exp. } & \multirow[t]{2}{*}{ Sim. } & \multirow[t]{2}{*}{ Exp. } & Sim. & Exp. & Sim. & Exp. & Sim. & Exp. & Sim. & Exp. & Sim. \\
\hline & $\mathrm{N}_{\mathrm{W}-\ln \mathrm{IO}^{\mathrm{b}}}$ & $\mathrm{N}_{\mathrm{w} \text {-Rietv }}$ & & & & & & & & & & & & & & & & & & & & & & \\
\hline 150 & 22.6 & $\begin{array}{c}16.1 \\
( \pm 1.3)\end{array}$ & 17 & $\begin{array}{l}24.626 \\
( \pm 0.003)\end{array}$ & 0 & $\begin{array}{c}8.9 \\
( \pm 0.9)\end{array}$ & 1.8 & $\begin{array}{c}0.3 \\
( \pm 0.5)\end{array}$ & 12.5 & $\begin{array}{c}1.3 \\
( \pm 0.9)\end{array}$ & 4.8 & $\begin{array}{c}4.7 \\
( \pm 0.7)\end{array}$ & 7.7 & $\begin{array}{l}12.6 \\
( \pm 0.3)\end{array}$ & 6.8 & $\begin{array}{c}12.9 \\
( \pm 0.1)\end{array}$ & 0 & 0 & 2.2 & 0 & 22.2 & 22.8 & 15.8 & 17.9 \\
\hline 200 & 9.1 & $\begin{array}{c}6.5 \\
( \pm 0.7) \\
\end{array}$ & 7 & $\begin{array}{l}24.611 \\
( \pm 0.001) \\
\end{array}$ & 0 & $\begin{array}{c}7.6 \\
( \pm 0.6) \\
\end{array}$ & 1.2 & $\begin{array}{c}0.3 \\
( \pm 0.5) \\
\end{array}$ & 10.5 & 0 & 8.6 & $\begin{array}{c}7.9 \\
( \pm 0.7) \\
\end{array}$ & 12.2 & $\begin{array}{c}14.2 \\
( \pm 0.6) \\
\end{array}$ & 7.3 & $\begin{array}{c}9.7 \\
( \pm 0.5) \\
\end{array}$ & 0 & 0 & 0 & 0 & 22.7 & 21.8 & 17.0 & 17.9 \\
\hline 250 & 5.3 & $\begin{array}{c}6.1 \\
( \pm 0.9)\end{array}$ & 6 & $\begin{array}{l}24.590 \\
( \pm 0.002)\end{array}$ & 0 & $\begin{array}{c}7.6 \\
( \pm 0.9)\end{array}$ & 4.0 & $\begin{array}{c}3.7 \\
( \pm 1.5)\end{array}$ & 9.6 & 0 & 6.4 & $\begin{array}{c}4.6 \\
( \pm 1.5)\end{array}$ & 12.2 & $\begin{array}{c}14.2 \\
( \pm 0.9)\end{array}$ & 7.8 & $\begin{array}{c}9.7 \\
( \pm 1.0)\end{array}$ & 0 & 0 & 0 & 0 & 21.8 & 21,8 & 16.2 & 18.0 \\
\hline 300 & 1.9 & $\begin{array}{c}4.1 \\
( \pm 0.6)\end{array}$ & 4 & $\begin{array}{l}24.445 \\
( \pm 0.001)\end{array}$ & 0 & $\begin{array}{c}1.5 \\
( \pm 0.5)\end{array}$ & 12.5 & $\begin{array}{c}14.5 \\
( \pm 0.5)\end{array}$ & 6.0 & 0 & 0 & $\begin{array}{c}1.0 \\
( \pm 0.5)\end{array}$ & 14.7 & $\begin{array}{c}20.4 \\
( \pm 0.5)\end{array}$ & 4.4 & $\begin{array}{c}2.5 \\
( \pm 0.5)\end{array}$ & 0 & 0 & 0 & 0 & 20.7 & 21.9 & 16.9 & 18.0 \\
\hline 350 & 0.4 & 0 & 0 & $\begin{array}{l}24.415 \\
( \pm 0.001)\end{array}$ & 0 & $\begin{array}{c}0.3 \\
( \pm 0.5)\end{array}$ & 14.6 & $\begin{array}{c}16.0 \\
( \pm 0.2)\end{array}$ & 0 & 0 & 0 & 0 & 20.4 & $\begin{array}{l}21.7 \\
( \pm 0.3)\end{array}$ & $3.2^{c}$ & $\begin{array}{c}2.0 \\
( \pm 0.2)\end{array}$ & 0 & 0 & 0 & 0 & 20.4 & 22.0 & 17.8 & 18.0 \\
\hline 400 & 0.0 & 0 & 0 & $\begin{array}{l}24.413 \\
( \pm 0.001)\end{array}$ & 0 & $\begin{array}{c}0.3 \\
( \pm 0.5)\end{array}$ & 15.0 & $\begin{array}{r}15.9 \\
( \pm 0.2)\end{array}$ & 0 & 0 & 0 & 0 & 19.4 & $\begin{array}{l}21.7 \\
( \pm 0.3)\end{array}$ & $2.3^{c}$ & $\begin{array}{c}2.0 \\
( \pm 0.2)\end{array}$ & 2.1 & 0 & 0 & 0 & 21.5 & 22.0 & 17.3 & 18.0 \\
\hline $\begin{array}{l}\text { Back } \\
\text { to RT }\end{array}$ & 0.0 & & & $\begin{array}{l}24.417 \\
( \pm 0.001)\end{array}$ & 0 & - & 15.6 & & 0 & - & 0 & - & 21.4 & & $2.0^{c}$ & - & 0 & - & 0 & & 21.4 & - & 17.6 & \\
\hline $150^{d}$ & 0.0 & & 0 & & - & $\begin{array}{c}7.5 \\
( \pm 0.7)\end{array}$ & - & $\begin{array}{c}6.0 \\
( \pm 1.2)\end{array}$ & - & $\begin{array}{c}0.2 \\
( \pm 0.5)\end{array}$ & - & $\begin{array}{c}2.0 \\
( \pm 1.2)\end{array}$ & - & $\begin{array}{l}13.6 \\
( \pm 0.6)\end{array}$ & - & $\begin{array}{c}9.0 \\
( \pm 0.1)\end{array}$ & - & $\begin{array}{c}0.3 \\
( \pm 0.5)\end{array}$ & - & 0 & - & 21.6 & - & 17.0 \\
\hline
\end{tabular}

a: Number of water molecules per unit cell estimated from the incoherent signal $\left(\mathrm{N}_{\mathrm{w}-\text {-nco }}\right)$, from Rietveld refinements $\left(\mathrm{N}_{\mathrm{w}-\text { Rietv- }}\right)$ and values used in Monte Carlo simulations ( $\mathrm{N}_{\mathrm{w}-\text { Sim. }}$ ). Note that $\mathrm{N}_{\mathrm{w}-\text { Inco }}$ was obtained from the mean intensity value of the incoherent signal in the $12-15^{\circ} 2 \theta$ range (free of diffraction peaks, stable level) for four patterns successively recorded at each steady temperature.

b: At temperatures below $150^{\circ} \mathrm{C}\left(20,40,60,80,100\right.$ and $120^{\circ} \mathrm{C}$, respectively), the unit cell parameter (a, in $\AA$ ) is $24.692,24.667,24.664,24.658,24.648,24.651$ and the water content deduced from the incoherent signal ( $\mathrm{N}_{\mathrm{w}-\mathrm{In} n}$, number per unit cell) is $91.8,80.9,73.8,64.0,52.7$ and 40.1

c: Location in off-centered sites II (appearing as sites II')

d: Cations distributions obtained by Monte Carlo simulations considering the dehydrated framework in place of that experimentally determined at $150^{\circ} \mathrm{C}$ 
Table 2. Distribution of $\mathrm{Ni}^{2+}$ cations located in Sites I' and II, in the various water environments described in Figure 10. Numbers per unit cell from Monte Carlo calculations are reported as a function of the water content $\mathrm{N}_{\mathrm{w}-S i m}$ used for simulations.

\begin{tabular}{|c|c|c|c|c|c|c|}
\cline { 2 - 7 } \multicolumn{1}{c|}{} & \multicolumn{2}{c|}{ I' } & \multicolumn{4}{c|}{ II } \\
\hline $\mathrm{N}_{\mathrm{w}-\text { Sim }}$ & SI'-noW & SI'-W $^{\text {sod }}$ & SII-noW & SII-W $^{\text {sod }}$ & SII-W & SII-W $^{\text {both }}$ \\
\hline 17 & $1.8 \pm 1.1$ & $2.9 \pm 0.4$ & $3.4 \pm 0.3$ & $3.2 \pm 0.1$ & $5.2 \pm 0.1$ & $1.1 \pm 0.1$ \\
\hline 7 & $6.6 \pm 0.8$ & $1.3 \pm 0.1$ & $4.6 \pm 0.8$ & $1.1 \pm 0.1$ & $4.0 \pm 0.2$ & 0 \\
\hline 6 & $3.9 \pm 1.7$ & $0.7 \pm 0.2$ & $4.7 \pm 0.6$ & $0.5 \pm 0.1$ & $4.5 \pm 0.5$ & 0 \\
\hline 4 & $1.0 \pm 0.5$ & 0 & 0 & $0.5 \pm 0.1$ & $2.0 \pm 0.4$ & $0.4 \pm 0.1$ \\
\hline 0 & 0 & 0 & $2.0 \pm 0.2$ & 0 & 0 & 0 \\
\hline
\end{tabular}




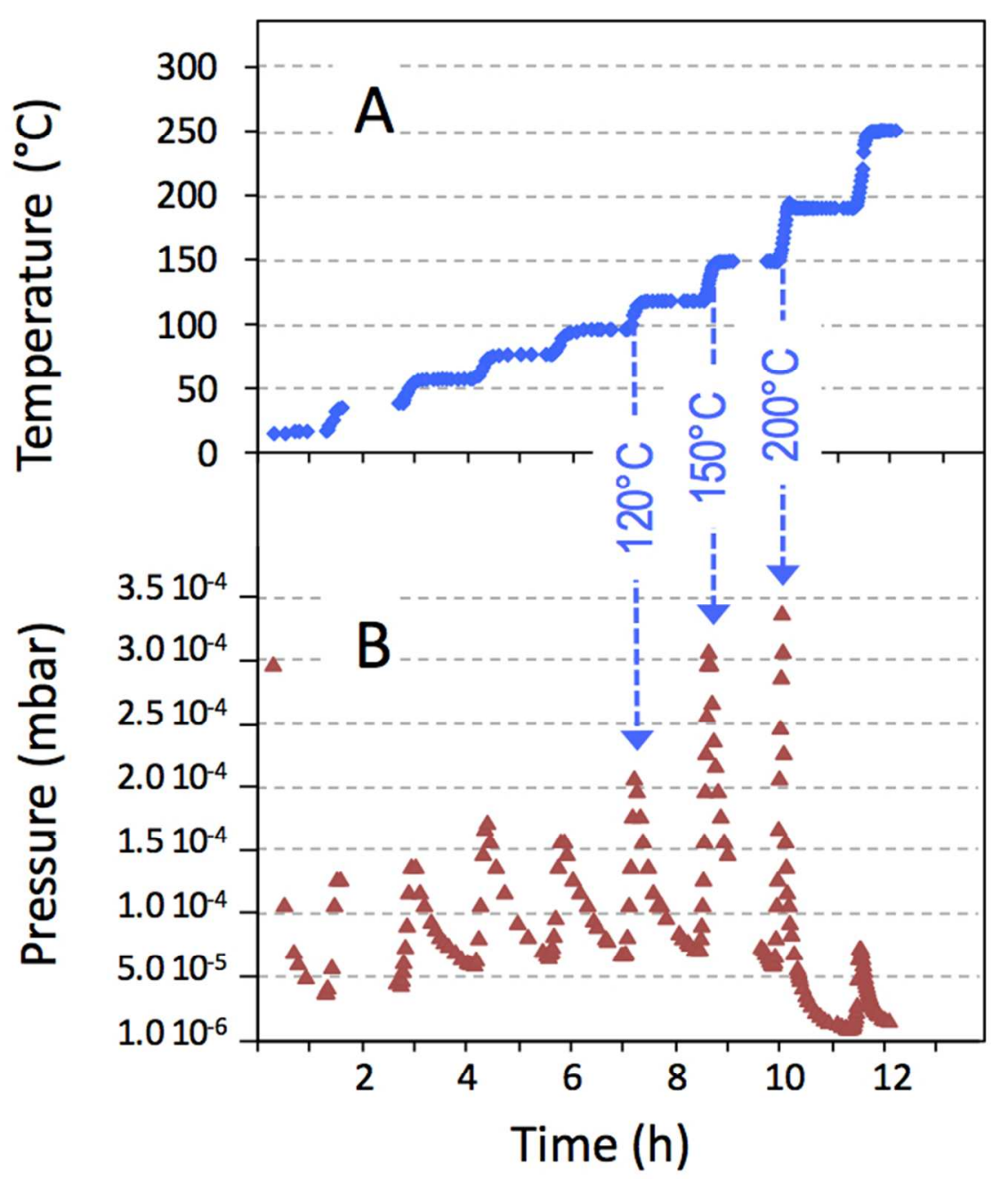

Figure 1: (A) Temperature profile of stepwise heating of Ni18Na22Y and (B) related evolution of the residual pressure in the vacuum furnace.

$137 \times 138 \mathrm{~mm}(150 \times 150 \mathrm{DPI})$ 


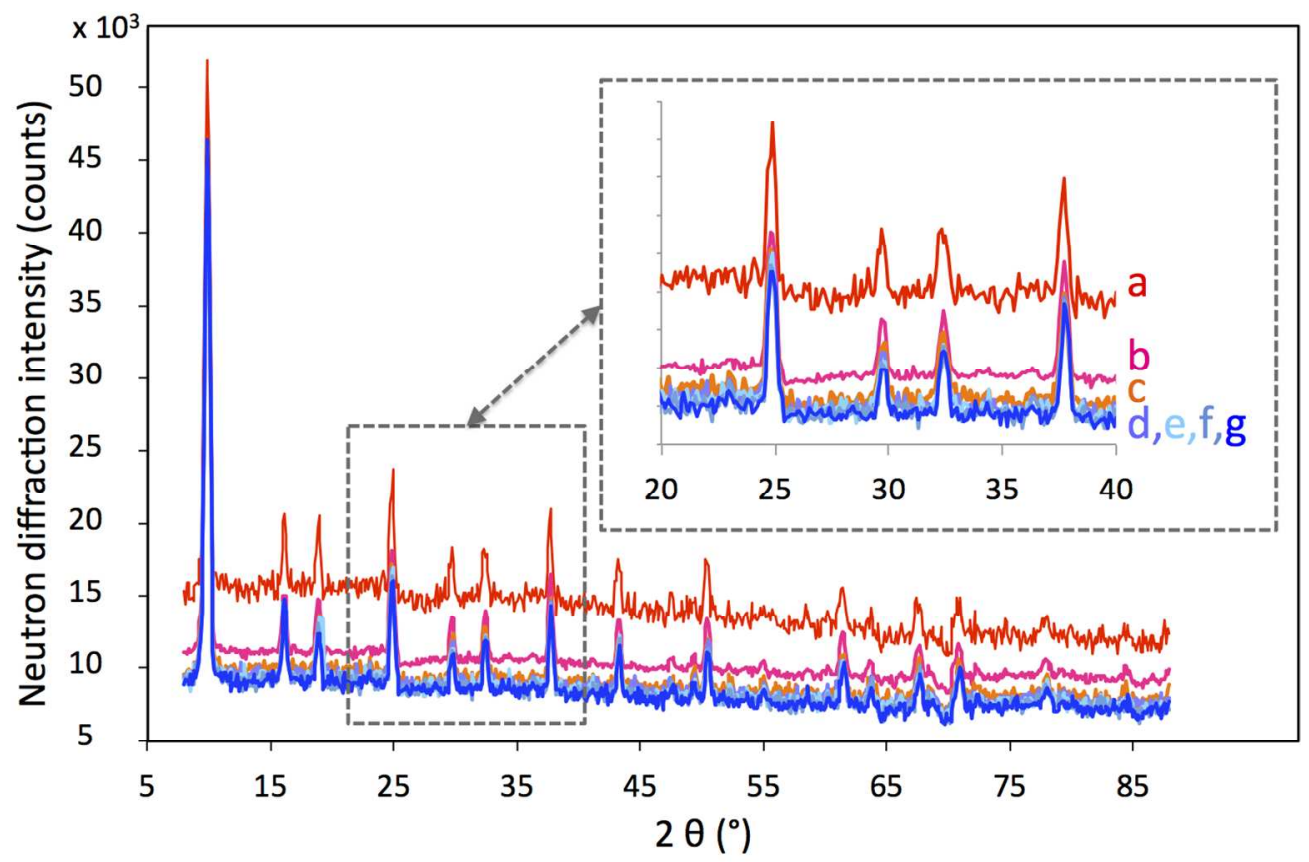

Figure 2: Neutron diffractograms of $\mathrm{Ni} 18 \mathrm{Na} 22 \mathrm{Y}$ : (a) before evacuation, (b) after evacuation at $20^{\circ} \mathrm{C},(\mathrm{c})$ during heating up to $40^{\circ} \mathrm{C}$ and $(\mathrm{d}-\mathrm{g})$ along the step at steady temperature of $40^{\circ} \mathrm{C}$. 


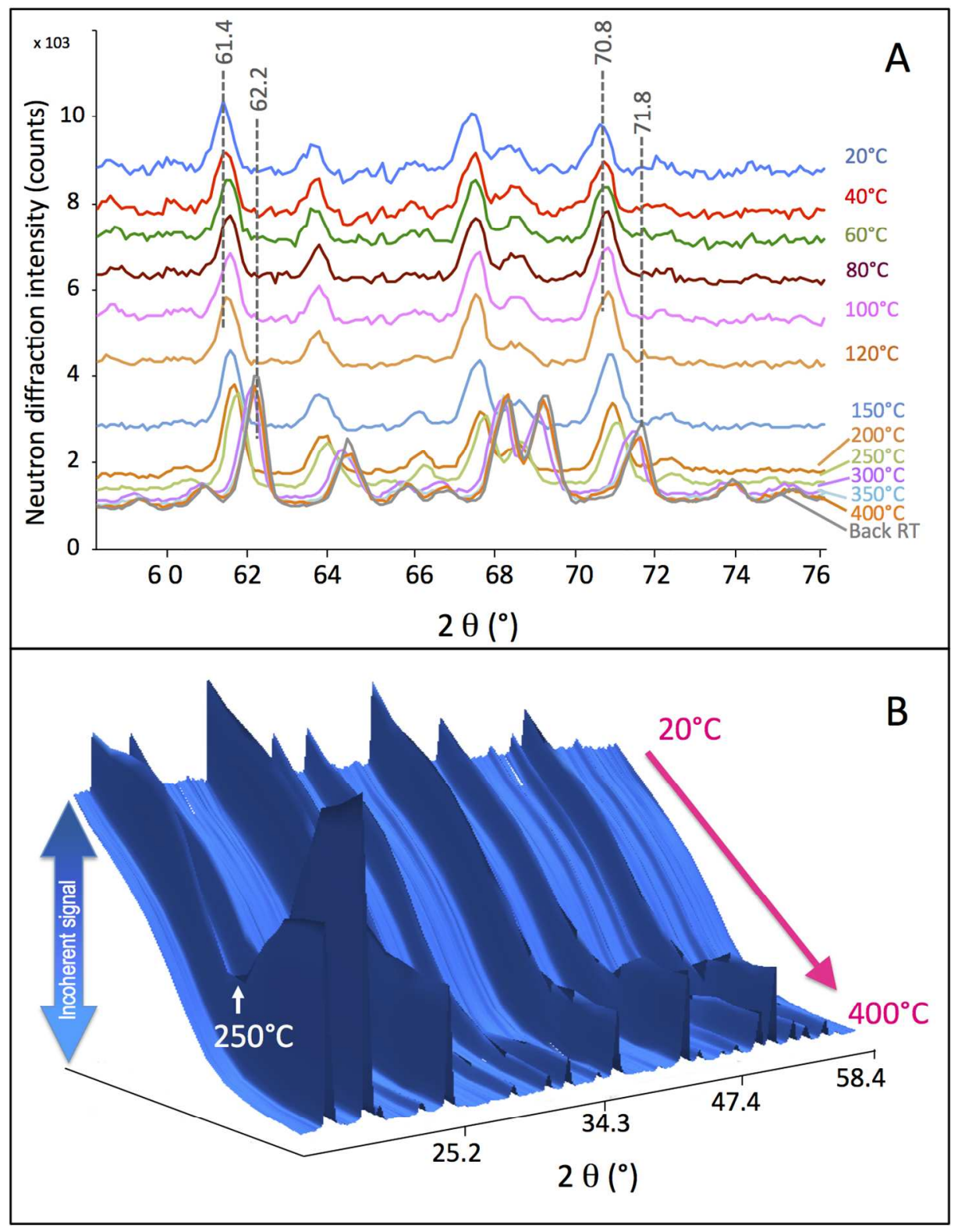

Figure 3: Evolution of the neutron diffraction patterns during heating of Ni18Na22Y previously evacuated at $5.5 \times 10-5$ mbar at $20^{\circ} \mathrm{C}$ for $20 \mathrm{~min}$ : (B) patterns in the $58-78^{\circ}(2 \theta)$ region showing the progressive decrease of the incoherent signal and the related shifts of diffraction peaks and (B) 3D representation in the $18-60^{\circ}(2 \theta)$ region highlighting the overall loss of incoherent signal together with changes in the relative intensities of the diffraction peaks. The reported diffractograms are the average of four patterns as systematically recorded at each steady temperature.

\section{$235 \times 304 \mathrm{~mm}(150 \times 150 \mathrm{DPI})$}




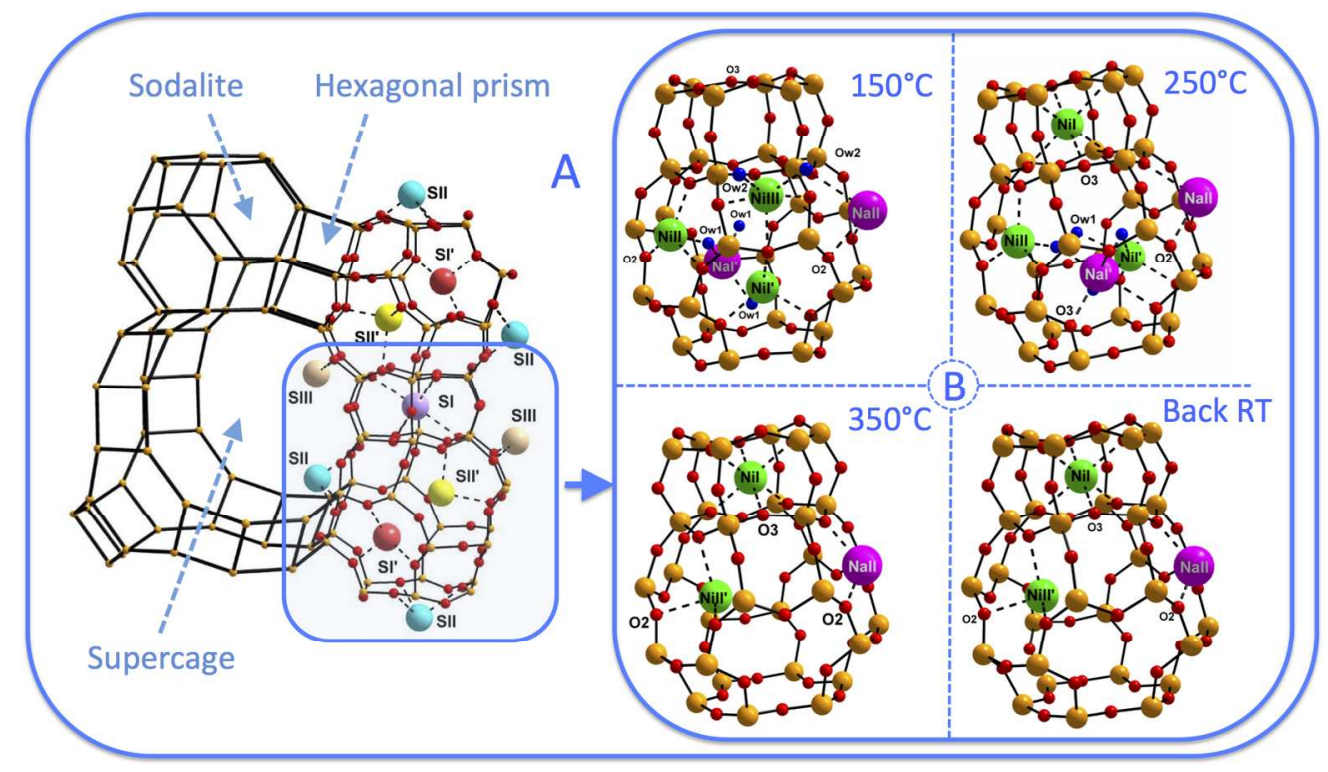

Figure 4: (A) Schematic representation of the FAU structure together with its constitutive cages and known position of crystallographic cationic sites I, I', II, II' and III (their total number per unit cell is 16, 32, 32, 32 and 48, respectively). (B) Experimental structures (clusters limited to a sodalite and a hexagonal prism) obtained from Rietveld refinement of the neutrons diffractograms of Ni18Na22Y after heating at varying temperatures under vacuum; the green $(\mathrm{Na}+)$ and pink $(\mathrm{Ni} 2+)$ balls show the identified cation positions without taking into account their distribution (which is detailed in Table 1). 

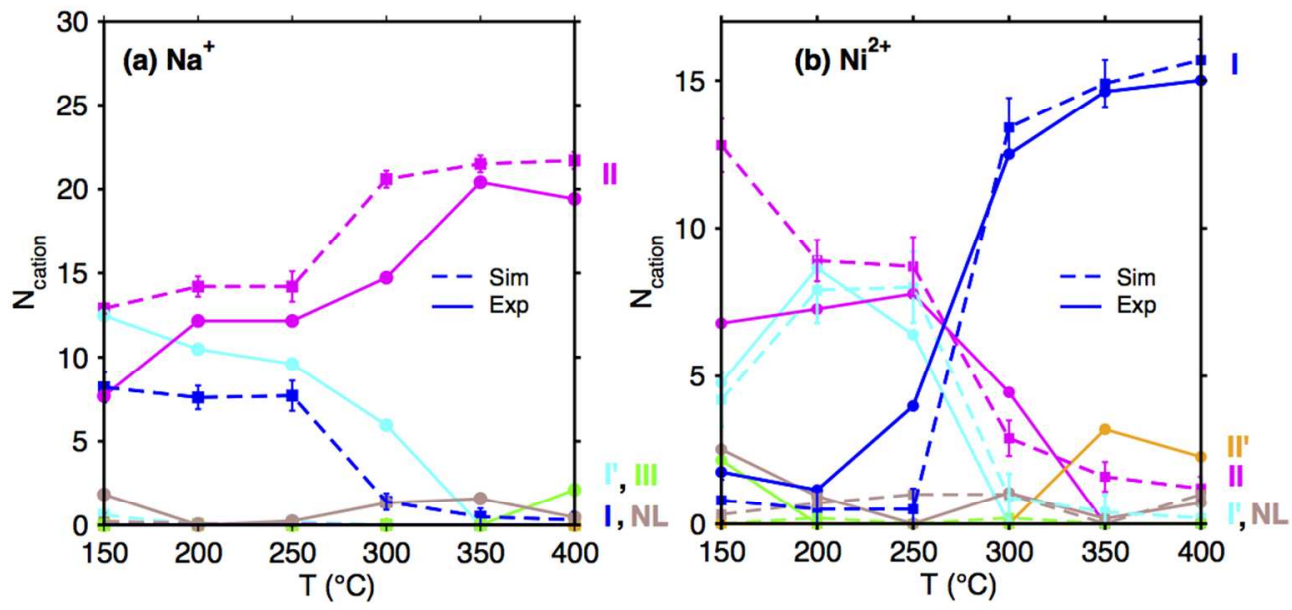

Figure 5: Evolution with temperature of the number per unit cell of (a) $\mathrm{Na}+$ and (b) $\mathrm{Ni2}+$ cations in each type of site (I, I', II, II' and III) as obtained from experiments (full lines) and from Monte Carlo simulation (dotted lines). NL refers to not located cations.

$$
195 \times 98 \mathrm{~mm}(150 \times 150 \mathrm{DPI})
$$


Figure 6: Structures showing the delocalization of site I ( $\mathrm{Na}+$ cations) with respect to the center of the hexagonal prism: delocalized site I from Monte-Carlo simulations for structures at a limited temperature (left structure) and comparison with site I identified as I' in Ni18Na22Y by Rietveld refinement (right structure). 


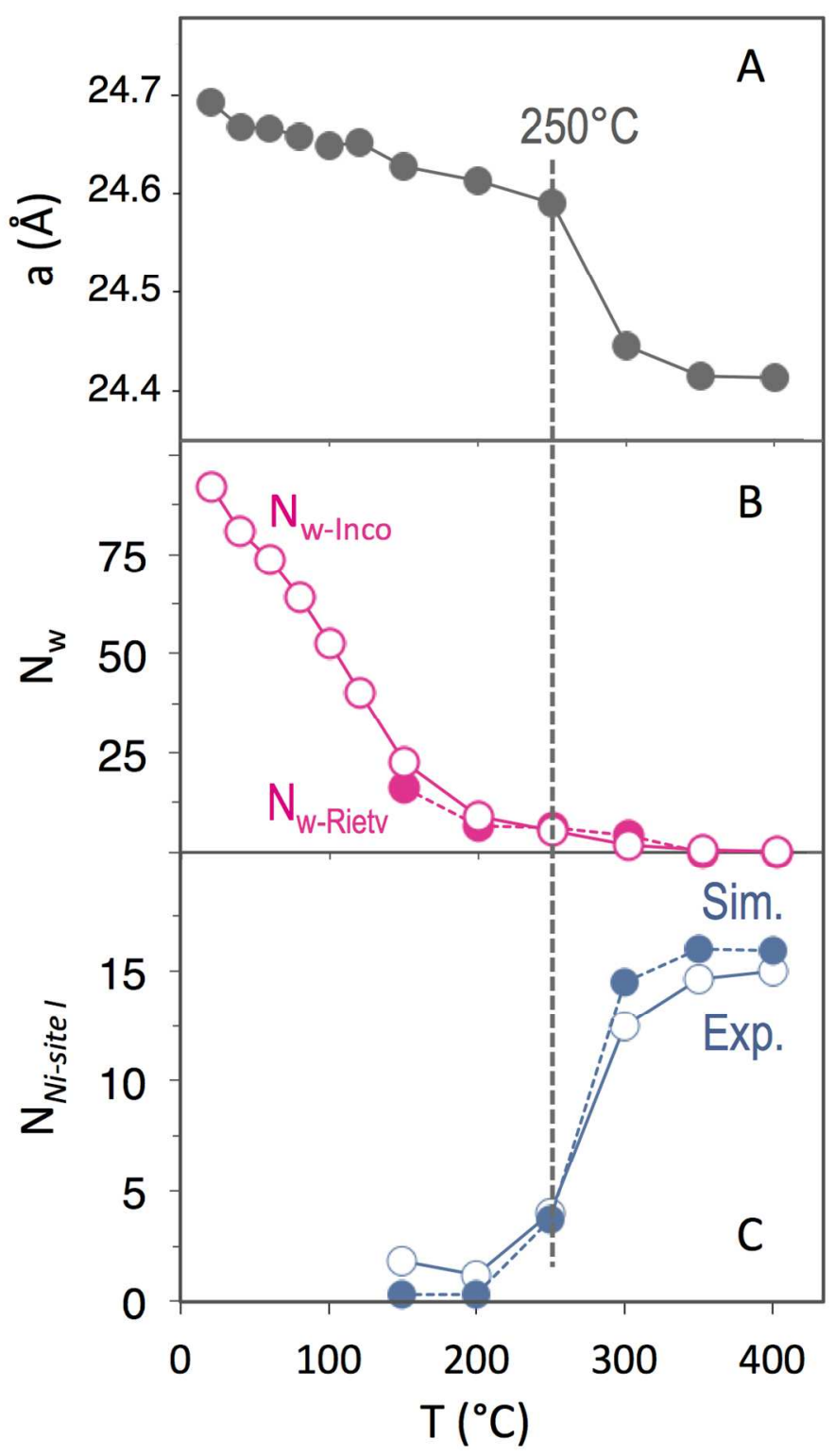

Figure 7: Evolution as a function of temperature of $(A)$ the experimental lattice parameter a, $(B)$ the experimental water content estimated from the incoherent neutron signal intensity (Nw-Inco, empty pink circles) and from Rietveld refinement (Nw-Rietv, full pink circles) and (C) the number of $\mathrm{Ni2}+$ cations in sites I deduced from experiments (empty blue circles) and from simulations (full blue circles). Numbers are given per unit cell. When the fully dehydrated sample at $400^{\circ} \mathrm{C}$ is brought back to room temperature under vacuum, all the properties remain unchanged (identical to those at $400^{\circ} \mathrm{C}$ ). 
Figure 8: Structural comparison showing the distortion of the hexagonal prisms depending on whether sites I are occupied by $\mathrm{Ni2}+$ ions (dry structure obtained at $400^{\circ} \mathrm{C}$, in red) or not (hydrated structure at $150^{\circ} \mathrm{C}$, in blue). 


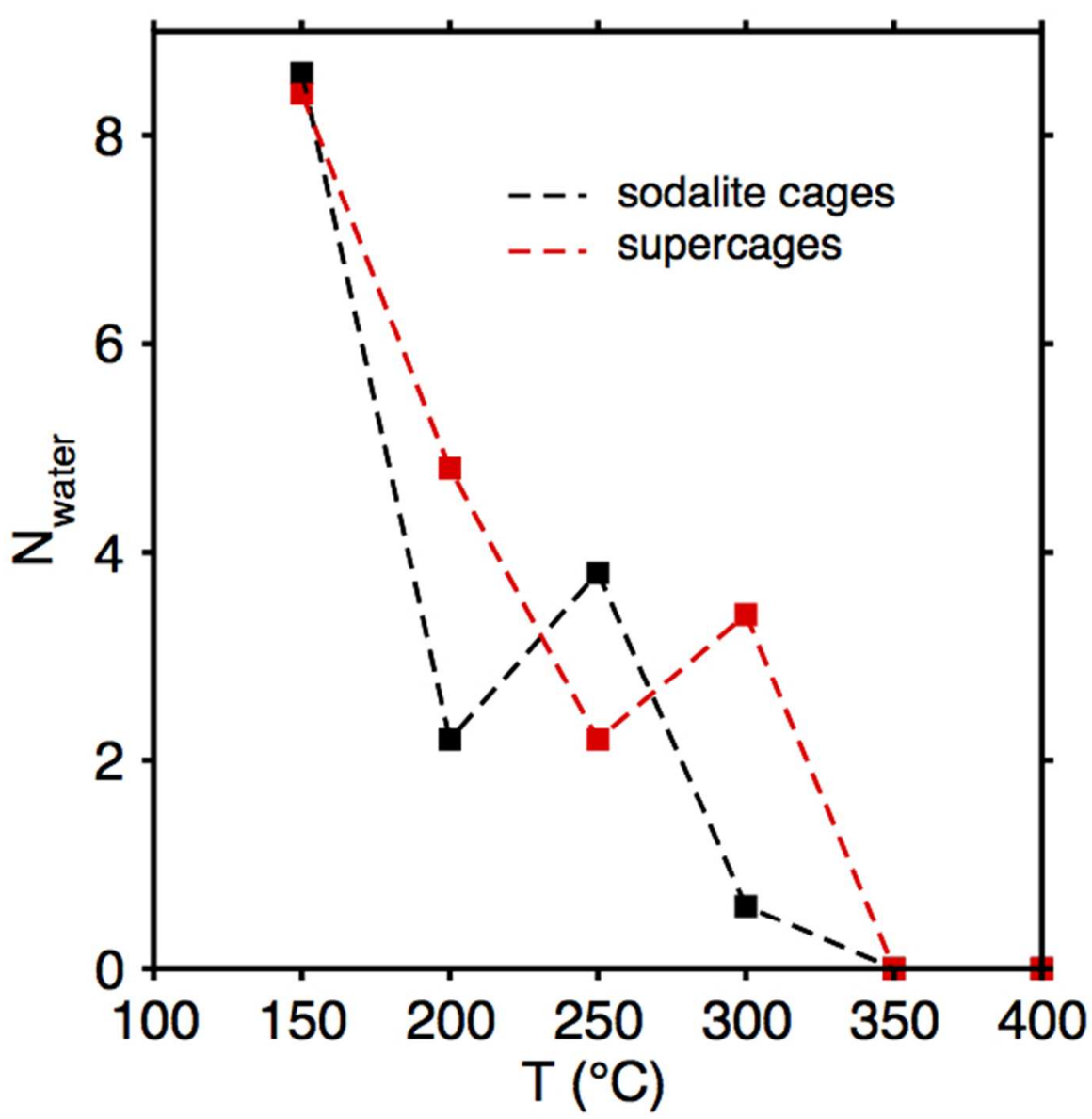

Figure 9: Evolution with temperature of the number per unit cell of water molecules located in sodalite cages and supercages as determined by Monte Carlo simulations.

$120 \times 116 \mathrm{~mm}(150 \times 150 \mathrm{DPI})$ 


\section{Site I'}

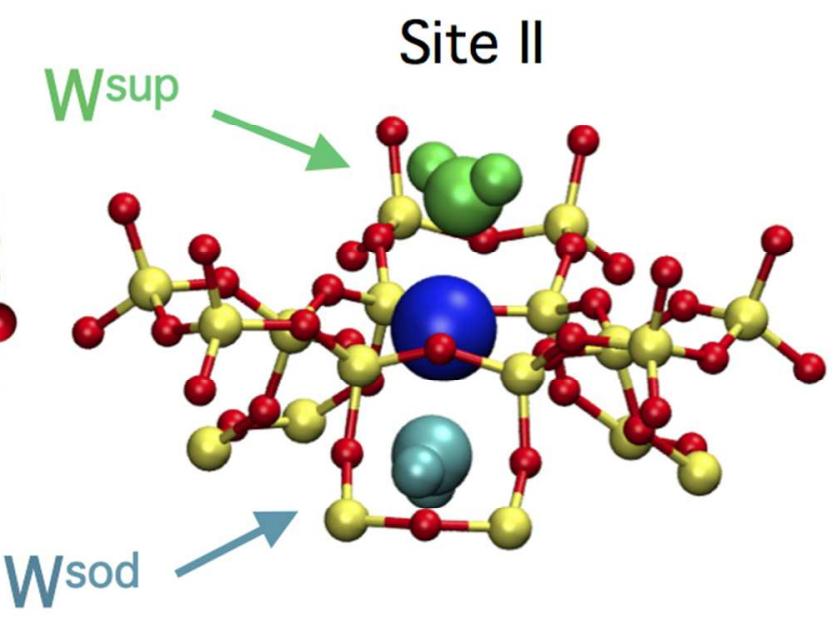

Figure 10: Identification by simulation of the possible hydrated $\mathrm{Ni2}+$ environments: $\mathrm{Ni2}+$ cations in sites I' can be hydrated by one water molecule in a sodalite cage (SI'-Wsod) whereas Ni2+ cations in sites II can be hydrated by one molecule in a sodalite cage (SII-Wsod) or in a supercage (SII-Wsup) or both (SII-Wboth). After full dehydration, Ni2+ can be still present in such sites but with no neighbor water molecule (SI'-noW and SII-noW). See Table 2 for the weights of these configurations as a function of water content. 